\title{
MomentDergi
}

Hacettepe Üniversitesi İletişim Fakültesi Kültürel Çalışmalar Dergisi

2019, 6(1): 99-129

ISSN: 2148-970X.

Makaleler (Tema)

\section{DEMOKRASI, POPÜLIZM VE YOK OLAN DOĞA}

\section{Uğur Baloğlu*}

Öz

Bu çalışma, dünyada ve özelde Türkiye'de gerçekleşen doğa tahribatlarının ekonomik kriz ve kültürel egemenlik arzusu ile ilişkisini, siyasal iktidarın popülizmi bir araç olarak kullanarak nasıl meşrulaştırdığını göstermeyi amaçlar. Son yıllarda dünyada popülist siyasetin yükselişi, popülizm ile demokrasi arasında kurulan ilişkiyi yeniden tartışmaya açar. Neoliberal politikaların uygulanmaya başlamasından sonra sıklaşan ekonomik krizler ve modern demokrasi anlayışında vuku bulan temsil sorunu, popülist liderlerin desteklenmesi için bir ortam hazırlar. Dünyanın birçok ülkesinde yükselen popülist otoriter siyasal dilin halk tabanında karşılık bulması, içinde bulunduğumuz kültürel ve toplumsal durumun açılanmasını zorunlu kılar. Çalışmanın birinci bölümünde, popülizm ve demokrasi arasındaki ilişkiyi Türkiye üzerinden örnekleyip demokrasideki eksen kaymasının nedenlerini inceliyorum. İkinci bölümde, doğanın bir yatırım aracı olarak sermaye tarafından tahrip edilmesini ve bu tahribatın popülist söylemlerle meşrulaştırılmasını tartışıyorum.

\section{Anahtar Terimler}

popülizm, ileri demokrasi, iklim değişikliği, doğa tahribatı, totaliter demokrasi

* Dr. Öğr. Üyesi, İstanbul Gelişim Üniversitesi Uygulamalı Bilimler Yüksekokulu ORCID ID: 0000-0002-7716-3663, ugurbaloglu@gmail.com Makalenin Geliş Tarihi: 15/03/2019 Makalenin Kabul Tarihi: 11/06/2019

(C) Yazar(lar) (veya ilgili kurum(lar)) 2019. Atıf lisansı (CC BY-NC 3.0) çerçevesinde yeniden kullanılabilir. Ticari kullanımlara izin verilmez. Ayrıntılı bilgi için açık erişim politikasına bakınız. Hacettepe Üniversitesi İletişim Fakültesi tarafından yayınlanmıştır. 


\title{
DEMOCRACY, POPULISM AND EXTINCTION OF NATURE
}

\begin{abstract}
In this article, it is aimed to show how to legitimize the relationship between the economic crisis and the desire for cultural sovereignty of the nature of the damage in the world, particularly in Turkey, by using populism as an instrument of political power. In recent years, the rise of populist politics in the world brings the relationship between populism and democracy up for discussion. The increasing economic crises after the neoliberal policies and the problem of representation in modern democracy provides an environment for the support of populist leaders. The populist authoritarian political language, which is rising in many countries of the world, supporting by the public requires the explanation of the cultural and social situation. In the first part of the study, I examine the causes of the axial dislocation in democracy by sampling via Turkey to the relationship between populism and democracy. In the second part, I argue that nature is destroyed by capital as an investment instrument and this is legitimated by populist rhetoric.
\end{abstract}

\section{Key Terms}

populism, advanced democracy, climate change, destruction of nature, totalitarian democracy

\section{Giriş}

Bilmek ve bilmemek, gerçeği görmenize karşı özenle hazırlanmış yalanları söylemek, birbirine karşıt iki kavrama, birbirleriyle çeliştiklerini bile bile inanmak, mantığa karşı mantık kullanmak,

ahlâka bağhllı̆̆ı ileri sürerken onu yadsımak...

(George Orwell, 1984)

Theodor Adorno (1998, s.111), Minima Moralia adlı yapıtında "hakikatin yalan, yalanın da hakikat gibi göründügü bir dönemeçteyiz şimdi" derken modern kurumların oluşturduğu kavramlarda meydana gelen epistemolojik kırılmayı niteleyerek günümüz dünyasında anlamlandırdığımız tüm eylem, söylem ve süreçlerin geçmişten farklı olacağını belirtir. 2016 yılında Oxford Dictionary tarafından yılın en popüler sözcüğü seçilen hakikat sonrası gerçeklik (post-truth) kavramı ${ }^{1}$ ile Adorno'nun tespiti arasında anlamlı bir bütünlük kurulabilir. Özellikle görsel-işitsel teknolojinin kültürün taşıyıcı aracı olduğu modern dünyada medya araçlarının insanların dış dünyaya ilişkin gerçeklik

\footnotetext{
1 Oxford Dictionary'e göre hakikat sonrası gerçeklik, nesnel olmayan olguların, nesnel olgulara göre toplumu yönlendirebilme potansiyeline sahip olduğu bir dönemi işaret eder. Ralph Keyes'in 2004 yılındaki Hakikat Sonrası Çă̆ kitabı ile popülerleşen kavram, herhangi bir konuda nesnel gerçekliklerin göz ardı edilerek duyguların ön plana çıkarıldığı bir tutum olarak tanımlanabilir (Tunçer, 2018, s. 370).
} 
algılarını yaratabilme kapasitesi üzerinden düşünüldüğünde, iktidar-medya arasında kurulan grift ilişki, hakikat kavramında bir anlam kayması yaratabilir. Bu durumun toplumsal alandaki karşlı̆ğı, popülist demokratik rejimde halkın seçtiği ve kendisini temsil ettiğini düşündüğü siyasal iktidarın tüm uygulamalarının toplumun çıkarını gözeterek yaptı̆̆ına inanma eğilimi olarak belirir. Dünyada, özellikle Donald Trump'ın seçimi kazanmasından sonra giderek yaygınlaşmaya başlayan popülist siyaset, Latin Amerika'dan Hindistan'a kadar farklı coğrafyalara kadar yayılmış durumda. Bu nedenle etki alanı giderek genişleyen popülizmi ve halk - iktidar (lider) arasındaki ilişkiyi anlamak için son dönemde popülizm üzerine yapılan çalışmaların sayısı artmaya başlamıştır.

Popülizmin son yıllardaki yükselişi ile ilgili The Guardian'ın yaklaşık 140 dünya liderinin söylemlerini analiz ederek gerçekleştirdiği çalışma önemli veriler sunar. Araştırma raporuna göre, 2000'lerin başından bugüne popülizm yükselen bir eğilimle dünyanın hemen her ülkesinde etkisini gösterir. Araştırma, popülizmin 2006 ile 2009 arasında Ekvador, Bolivya ve Çek Cumhuriyeti'nde popülist liderlerin iktidara gelmesiyle önemli ölçüde arttığını ve Türkiye ve Rusya'da popülist söylemlerin kullanılmaya başladığını belirtir. ${ }^{2}$ Farklı coğrafyalarda halkı etkileyen liderlerin popülist söylemlerine dikkat edildiğinde, belirli noktalarda kesiştiği söylenebilir. Popülist liderler, özellikle hakikatin giderek muğlaklaştığı günümüzde, demagojinin yükselişi ile nesnelliğin özelliğini yitirmesiyle birlikte genellikle din, milliyet gibi soyut kavramları kullanma eğilimi gösterirler. Bu tarz bir siyasetin yapılabilmesi için gereken ortamı sağlayan en önemli araçlarından biri, lider ile halk arasında iletişimi sağlayan medyadır.

Teoride medya organı, demokratik öğretiye göre bağımsız bir yapıya sahiptir ve gerçeğin ortaya çıkması için mücadele eder. Bu bakış açısına göre medyanın, ulusal ya da uluslararası bütün olayları, eylemleri, fikirleri ve/veya sorunları iktidar perspektifinden yansıtmaması gerekir. Günümüz parlamenter demokrasi ve medya arasında var olan temel sorun budur. İktidarın kendi meşruiyet alanı olarak kullandığı

\footnotetext{
${ }^{2}$ Çalışmaya göre popülizm ile ilgili en önemli gelişme, son beş yılda, Orta ve Doğu Avrupa'da artan sayıda popülist liderin iktidara gelmesiyle ve ABD'de Donald Trump, Hindistan'da Narendra Modi ve Brezilya'da Jair Bolsonaro'nun seçilmesidir. Ayrıca çalışmada Türkiye ile ilgili veriler de dikkat çekicidir. Zira Türkiye'nin siyasal lideri, günümüzde çok popülist olup Latin Amerikalı olmayan, tek sağcı lider pozisyonundadır. 16 yıl boyunca iktidarda bulunan lider, 2003 yılında popülist değil olarak nitelenirken ülkenin politik sisteminin ne kadar değiştiğini anlamak için önemli bir veri sunar. Çalışma sonuç olarak 17 yıl önce yaklaşık 120 milyon kişiyi yöneten popülist liderler, bugün 2 milyardan fazla insanı yönetmektedir (Lewis vd., 2019).
} 
medya araçlarının bir denetim mekanizması olmaktan çıkıp iktidarın bir çeşit söylem alanı olarak yapılandırılması, toplumsal alanda gerçekliğin biçimbozumuna neden olur.

Popülist söylemlerle gerçekliğin biçimbozumuna uğraması, günümüz endüstriyel toplumların üzerine inşa edildiği rasyonel, pozitivist bakışın göz ardı edilerek hakikat sonrası dönemde uygulanan politikaların duygulara yönelik hareket ettiğini gösterir. $\mathrm{Bu}$ durum doğruluk, dürüstlük gibi kavramların yeni politik düzlemde önemsizleştiğini işaret eder. Kavramların anlamını yitirdiği veya değiştiği bu yeni ortamda araçsallaşan aklın doğa ile kurduğu ilişki biçimini meşrulaştırma çabası, günümüz popülist siyasal söylemlerinde sıklıkla ulusal kimliğe yapılan vurgu ile ortaya çıkar. Diğer bir deyişle, hakikat sonrası siyasal iktidarın kullandığı popülist dil, ulusun, kültürün olumlanması en büyük olma tahayyülü- çerçevesinde belirlenir. Konu ile ilgili Appadurai, içinde bulunduğumuz demokrasi krizini aşmak için siyasal liderlerin kullandıkları dilin ulusal ekonomiyi yönetemiyor olmalarından kaynaklı olduğunu belirtir. ${ }^{3}$ Ekonominin dışa bağımlılığı nedeniyle kriz yaşayan siyasal iktidar içinde bulunduğu krizi aşmak için doğayı nesneleştirme yoluna giderek hem küresel sermayeyi besler hem de halka/millete hizmet anlayışını benimsediğini göstererek halkın takdirini kazanmaya çalışır.

$\mathrm{Bu}$ çalışma siyasal otoritenin ekonomik ve toplumsal krizleri aşmak için doğayı sermayenin tahakkümünde bir araç olarak kullandığını iddia eder. Buna göre soyut kavramlar ve duygular üzerine temellenen popülist politikaların geleceğin ekonomi politikalarını belirleyeceği savından hareketle, ekonomik ve toplumsal krizlerin kısa vadeli çözümleri için doğanın tahrip edilmesi gelecekte daha büyük problemleri beraberinde getirecektir. Çalışma siyasal iktidarın doğa üzerinde kurduğu tahakküme gelecekte iklim değişikliği tehlikesini yaratma potansiyelini de içinde barındırarakmeşruiyet kazandıran popülizmin bir araç olarak kullanıldığını göstermeye çalışacaktır.

\section{Gerici Popülizm ile İleri Demokrasi Mümkün mü?}

Yirminci yüzyıl, dünyada değişen siyasal modellerin demokratik bir yapı üzerinde inşa edilmeye çalışıldığı ancak yine de savaşlar, totaliter eğilimler, faşist söylemler gibi kimi olumsuz gelişmelerin demokratik düşünceyi yıprattı̆̆ı, hatta demokrasinin salt teoride

\footnotetext{
${ }^{3} \mathrm{Bu}$ sorun küresel kapitalist ekonominin bir sonucu olduğundan bütün ülkeler için geçerlidir. Appadurai (2017, s.18) en zengin veya en fakir ülke için problemli alanın aynı olduğunu iddia eder ve der ki; "ABD ekonomisinin azımsanmayacak bir kısmı Çin'in elinde, Çin için Afrika, Latin Amerika ve diğer Asya ülkelerinden gelen hammadeler elzem, herkes bir ölçüde Ortadoğu petrolüne ihtiyaç duyuyor ve tüm modern ulus-devletler küçük bir sayı oluşturan zengin ülkelerden gelişmiş silah ve mühimmat satın almaya mecbur."
} 
konuşulabileceği pratikte uygulamanın zor olduğunu gösteren tarihte eşine rastlanmaz bir zaman dilimini işaret eder. Yirminci yüzyılın sonlarına doğru Sovyetler Birliği'nin dağılması ile birlikte dünyada sağ söylemlerin baskın hale gelmesi demokratik aşınmanın başladığının sinyallerini verir. Ancak buna rağmen özellikle 2000'li yılların başlarından itibaren Gürcistan, Ukrayna, Kırgızistan, Tunus'daki renkli devrimlerle görece yeşeren demokratik umutlar, bu ülkelerde devrim sonrasında siyasal düzensizliklerin ortaya çıkmasıyla demokratik olmayan rejimle yönetilen diğer ülkelerde bir anlamda yok olur. 1990'larda akademisyenler, düşünürler genellikle otoriter rejimlerin geçici olduğunu, bununla birlikte demokrasiye doğru büyük bir ivmenin gerçekleşeceğini beklerken (Platter, 2010, s.81) demokrasi bilincinin yerleşmediği toplumlarda oluşan siyasal boşlukların çeşitli güçlerin iktidar savaşına dönüşmesiyle toplumsal hak ve özgürlüklere ulaşmayı hedefleyen halk için tersi bir durumla sonuçlanır.

Hakikat sonrası çağda değişen kavramlar, gerçekler, politikalar demokraside de bir anlam kayması yaratır. Neoliberal politikalarla birlikte medyada meydana gelen yapısal dönüşüm ve siyaset-medya arasında kurulan grift ilişkiler, medyanın toplumu bilgilendirici işlevini kamu yararına değil, siyasal iktidar ve sermaye yararına yerine getiriyor olması, nesnel hakikatlerin giderek popülist söylemlerle birlikte anlamını yitirmesine neden olur. Bu durum özellikle son yıllarda kavramların yaşadığı anlam erozyonunu anlamlandırabilmek adına önemlidir. Günümüzde toplumsal alanın homojenleştirilmeye çalışılması için bir yöntem olarak kullanılan popülizm, halkı topyekûn bir varlık olarak görür. Tek kimlikli, homojen toplum tahayyülü ile temsili demokrasi çerçevesinde halk adına konuşanın kendisi olduğu yanılsamasını yaratır ve bu durum gelişmekte olan demokrasinin ileri bir aşaması olarak betimlenir.

\section{Türkiye’de İleri Demokrasi Anlayışı}

2012 yılında Türkiye'deki siyasal iktidar, Adalet ve Kalkınma Partisi (Ak Parti), İleri Demokrasi Yolculuğu isimli bir kitap yayımladı. Aynı yıl, Ak Parti'nin iktidara geldiği 3 Kasım günü dönemin Başbakanı Twitter hesabından "ileri demokrasiye, hak ve özgürlüklere inanan bir anlayış geldi"4 şeklinde bir paylaşım yaptı. Türkiye'nin tarihini, demokrasi mücadeleleri tarihi olarak belirten ve bunun hala gerçekleşmediğini söyleyen Kemal H. Karpat'tan (1996, s.23) hareketle henüz demokrasinin tam yerleşmediği Türkiye'de iktidarın ileri demokrasi çıkışları nasıl anlamlandırılabilir? Birden fazla

${ }^{4}$ https://twitter.com/rt_erdogan/status/264675211675332609 
etkenin kesişiminde yer alan ileri demokrasi söylemi, ilkin halkın doğrudan söz hakkı olduğunu vurgular ve bunu sürekli halk oylaması, referandum süreçleri ile yineler. Genellikle 'halk egemenliği', 'milletin adamı' gibi sloganların yer aldığı söylem biçimlerini kullanan bu tavır özü itibariyle popülizmden beslenir. Özellikle 2012 yılından sonra sıklaşan ileri demokrasi kavramına yapılan bu vurgular ile siyasal iktidarın uygulamaları arasındaki ilişkiyi göstermek günümüz toplumunun siyasal tercihlerini anlamak adına yol göstericidir.

Türkiye'nin demokrasi mücadelesi tarihi, sürekli kesintilere uğrayan ve dişsal müdahalelerle yeniden onarılmaya çalışılan; aynı zamanda halk tabanından bir refleksin değil genellikle iktidar -yöneten kesim- tarafından yönlendirilen bir süreci işaret eder. Hali hazırda çok uzun olmayan ve belirli aralıklarla müdahalelere uğrayan -hem siyasal iktidar hem de ordu tarafından- demokratikleşme çabalarının tepeden inmeci bir bakışla demokrasinin kurumsallaşmasına engel olduğu söylenebilir. Demokratikleşme çabalarındaki başarısızlığın diğer bir nedeni de toplumun demokratik öğretiyi bilmemesi, içselleştirememesi ve kavramı kendi çıkarları doğrultusunda uygulanabilir bir sistem olarak kabul etmesidir. ${ }^{5}$ Zira günümüz parlamenter demokrasi anlayışı Batı'nın aydınlanmacı tavrı ile dünyaya yayılan modernleşmenin bir sonucudur. Doğu ve Batı kültürünün -siyasal, toplumsal vb.- geçmişten bugüne kurumsal farklılıklara sahip olması, Batı kültüründen devşirilen siyasal modelin uygulanmasında sorunların ortaya çımasına neden olur. Bu bakımdan Türkiye'de demokrasinin gelişimi, Batı ülkelerinde olduğu gibi özgürlük, güven ve eşitlik vurgusu yapılan toplumun tamamını kapsayan bir anlayıştan ziyade "antik demokrasinin saflığı düzeyinde kalmıştır... Bu anlamda Türk demokrasisi bütün modern donanımına rağmen, dünyanın en arkaik demokrasilerinden biridir" (Bilge, 2011, s.54). Günümüzde siyasal iktidarın ileri demokrasi hakkındaki popülist söylemlerinin ana dayanak noktası ise buradan temellenir.

Cumhuriyetin kurulduğu yıllar referans alınarak, tek partili dönemde toplumun bilinçli bir şekilde kültürel ve dini geleneklerinden koparıldığı şeklindeki söylemler ve çok partili hayata geçiş sonrası toplumun çoğunluğunun verdiği oyların devletin baskı araçları tarafından yok sayılarak siyasal iktidarın tasfiyesine yapılan göndermeler

\footnotetext{
${ }^{5}$ Konu ile ilgili Emre Kongar (2001), Türkiye'de demokrasinin kültürel ve siyasal-ideolojik iki unsur nedeniyle gelişemediğini belirtir. Bunun asal nedenlerini ise Türkiye'nin endüstrileşme sürecine geç entegre olmasına ve seçmen tabanını geniş köylü halk kitlesinin oluşturmasına bağlar.
} 
parlamenter demokrasinin işlevsiz olduğu yönünde bir kanı oluşturur. ${ }^{6}$ Benzer şekilde parlamenter sistemde koalisyon ortaklarının çatışmaları, siyasal mekanizmanın işlerliğini yok etmeye neden olabilmekte ve bu süreçte ekonomi negatif olarak etkilenmektedir. Türkiye'de demokrasi krizi olarak adlandırılabilecek bu gibi durumların çözüme kavuşturulması ise paradoksal bir şekilde demokratik taleplerin kısmi olarak askıya alınması ile gerçekleştirilmiştir. Yukarıda bahsedildiği üzere Türkiye'de demokrasi rejimi halk tarafından benimsenen ve korunan bir yönetim şeklinden çok farklı kurumların güvencesi altında korumaya alınmış bir sisteme benzemektedir. Bu bağlamda Türkiye siyasal tarihindeki tüm olumsuzlukların medya araçları vasıtasıyla birer propaganda malzemesi olarak sunumu, hakikat sonrası çağda siyasal iktidarın kendi belirlediği kurallar çerçevesinde yapılandırılmış bir demokrasi rejimine geçiş için bir ortam oluşturur. Bu ortamda genellikle halk iradesine yapılan vurgular önem arz eder. İleri demokrasi olarak nitelenen rejimin Laclau'nun Canovan'dan aktardığı popülist demokrasi $(2007$, s.18) arasındaki benzerlikler ise bu vurgular üzerinden temellenir.

Popülizm ile ilgili çalışmalar günümüzde aşırı sağın yükselişi ile birlikte popüler olsa da kavramın pratikte uygulanması Cumhuriyetin ilk yıllarına kadar uzanır. Türkiye'de popülizmin siyasi alanda kullanımı iki farklı tür üzerinden sinıflandırılabilir:

${ }^{6}$ Carl Schmitt (2006, s.10) bu durumu bir yönetim biçimi olarak parlamenter sistemin içinde bulunduğu krizi tartışır. Özellikle yirminci yüzyıl sonrasında siyasal partilerin çıkar peşinde koşmaları nedeniyle giderek işlevini yitiren, seçmen-seçilen arasındaki temsil mekanizmasının giderek yok olduğu bir yönetim biçimine evrildiğinden parlamenter demokrasinin kriz içinde olduğunu belirtir: "Parti hakimiyeti, partilerin sübjektif -kişisel- politikaları, "amatörler hükümeti", süregiden hükümet krizleri, parlamento konuşmalarının amaçsızlığı ve banalliği, parlamenter teamüllerin giderek düşen seviyesi, parlamento tıkanıklığına yol açan yıkıcı yöntemler, dokunulmazlık ve ayrıcalıkların parlamentarizmi hor gören radikal muhalefet tarafından istismar edilmesi, onursuz işlerin gündelik pratik haline gelmiş olması, parlamentoya devam oranının düşük olması... Nisbî temsil ve liste sisteminin seçmenle milletvekili arasındaki bağı kopartması, hizipçiliğin vazgeçilmez bir araç haline gelmesi ve temsil prensibi olarak adlandırılan prensibin anlamsızlaşması; dahası gerçek faaliyetin, genel kurulun kamuya açık görüşmelerinde değil, aksine komitelerde gerçekleşmesi ve önemli kararların hizip liderlerinin ve hatta parlamento dışı komitelerin gizli toplantılarında alınması sureti ile her türlü sorumluluğun devredilip ortadan kaldırılmasıyla bütün parlamenter sistemin, partilerin ve ekonomik çıkar sahiplerinin hakimiyetini gizleyen kötü bir vitrin haline gelmesi...". Benzer şekilde Fuat Keyman (2008, s.7,8), Türkiye üzerinden parlamenter sistemin giderek işlevsizleştirildiğini belirtir. Böylece siyasi partiler, Türkiye'deki toplumsal, ekonomik sorunlara çözüm bulmak yerine kendi çıkarlarını göz önünde bulunduran politikalar izleyip "siyasi rant ve ekonomik nema" kazanmaya çalışan yapılara dönüşüyor. Siyasi partiler ile toplum arasında giderek zayıflayan bağ bir çeşit güven problemi yarattığından demokrasinin olumsuzlanmasına neden olabiliyor. Keyman, on yedi yıldır iktidar olan AK Parti'nin arka arkaya seçimi kazanmasında bu olguların önemine vurgu yapar. 
Entelektüel popülizm ve siyasi popülizm (Toprak, 1992, s.62, 63). Erken cumhuriyet döneminde uygulanan "solidarist ve korporatist halkçılık ilkesi"nin temsil ettiği entelektüel popülizm, çok partili hayatın başlaması ile birlikte toplumun siyasal katılımı sonrası siyasi popülizme evrilmiştir (Baykan, 2017, s.165). Popülizmin tavır değiştirmesi, modernleşme yanlısı seçkinlerin karşısında yer alan muhafazakar kesimin iktidarı ele geçirmesinden sonra gerçekleşmiştir. İlk yıllarda toplumu Batılı tarzda yeniden biçimlendirme misyonu yüklenen seçkin-azınlığa karşı İslamist söylemlerle toplumla popülist bir ilişki kuran muhafazakâr muhalif taban, Menderes, Demirel, Özal gibi liderlerle tavrını belirli bir çizgide korumuştur (Belge, 2018, s. 8). Ancak bu çizgi, 2002 y1lında iktidara gelen Erdoğan hükümeti ile birlikte sert söylemlerle öfkenin dışavurumu şeklinde açı̆̆a çıkan bir tavra dönüşmüştür. Konu ile ilgili Pankaj Mishra (2017, s. 128), günümüzde siyaset yapma biçiminin hınç, öfke gibi duygulardan beslendiğini; bunun da aydınlanmanın karanlık mirasından kaynaklandığını belirtir. Zira popülizmin beslendiği kaynaklardan biri haksızlığa uğramış bir halk portresidir. Ancak Mishra'nın popülist liderlerin söylem biçimlerine yaptığı vurgu Türkiye üzerinden incelendiğinde Erdoğan'ın söylemlerinin salt öfkeden beslendiğini söylemek doğru olmaz. Toplumsal temsili ben ve öteki ayrımı üzerinden şekillendirilen söylemler, 'ben' üzerinden yapılandırıldığında topluma hizmet eden, toplum için çalışan; halkın içinden gelen ve onlar gibi konuşan, davranan -Fenerbahçeli, Kasımpaşalı veya Rizeli olmak gibi- hatta onlar gibi kızan veya şefkat gösteren bir söylem alanı içerisinde inşa edilir. Aynı şekilde öteki olan ortak düşman konumunda belirlenip çoğunluğun öfkesini kustuğu -enerjisini boşalttı̆̆ı-, toplumsal problemlerin ana nedeni olarak nitelenen hınç siyasetine maruz kalır. Bu tarz popülist siyaset biçiminin ortaya çıkışı ile neoliberal politikaların yarattığı toplumsal krizlerin arasında anlamlı bir ilişki vardır.

1980 sonrası dünyada yaygınlaşan neoliberal politikaların Türkiye'yi de etkilemesi ile birlikte çoğulcu demokrasi anlayışının çoğunlukçu demokrasiye dönüşümü bugün içinde bulunulan totaliter demokrasinin başlangıç aşamasını oluşturur. 1982 anayasasının meclise girecek partilere getirdiği yüzde 10 baraj şartı da bu çoğunlukçu demokrasinin temel belirleyicisidir. Bu tarz bir demokrasi anlayışında toplumun çoğunluğu, seçtiği kişi ya da partiye tam yetki vererek azınlığın talepleri yok sayılmaya başlanır. Bu durum siyasal iktidardaki kişi ya da kurum tarafından kullanılarak yeni bir toplumsal bilinç inşası için uygun zemin oluşturur. Toplumun çoğunluğunu oluşturan bu bilince sahip kesim, siyasal iktidarın uyguladığı tüm politikaları onaylamaya hazır bir kitledir. Çünkü ileri demokrasi olarak adlandırılan bu dönemde çoğunluğu temsil eden kesim -eğitimli ya da eğitimsiz olsun- ile iktidar tek vücut olur. Diğer bir deyişle siyasal 
parti ne kadar süre iktidarda kalırsa ona oy veren kesim de o kadar (toplumsal alanda) iktidarda kalacaktır düşüncesi yaratılır.

Bu noktadan şu soruyu sormak toplumun günümüz otoriter yönetim biçimini onaylayan tavrını anlamak ve açıklamak için önem arz eder: İleri demokrasi olarak belirtilen yeni yönetim biçimi ile popülist söylem ve çoğunlukçu demokrasi arasında nasıl bir ilişki mevcuttur? Günümüzde siyasal iktidar, Türkiye'de demokrasinin kurumsallaş(a)mamasını geçmiş dönem hükümetlerinin ve ordunun vesayetçi yapısına dayandırır ve tek parti dönemindeki demokrasi anlayışının, azınlığın kararlarının çoğunluğa tahakkümü olarak yansıtıldığını düşünür (Erdem ve Coşkun, 2009 , s.7-9; Demirkent, 2013, s.9-11).7 Bununla birlikte Osmanlı ve Türk toplumunun siyasal, toplumsal, kültürel özelliklerinin, demokrasinin kurulmasındaki temel engeller olduğunu düşünen araştırmacılar da mevcuttur. ${ }^{8}$ Bu bağlamda demokrasi öncesi siyasal geleneğin günümüzde Yeni Osmanlıcılık söylemleri ile yeniden üretilmeye çalışılması

\footnotetext{
7 Tek parti zihniyeti ile ilgili Recep Tayyip Erdoğan'ın konuşmaları için; https://www.tccb.gov.tr/haberler/410/32353/milletimiz-bizimle-birlikte-yeni-turkiyeyi-yeni-anayasayi-vebaskanlik-sistemini-istiyor, https://www.tccb.gov.tr/haberler/410/32254/artik-eski-turkiye-olmayacaksimdi-yeni-turkiyeyi-insa-edecegiz, https://www.aa.com.tr/tr/turkiye/cumhurbaskani-erdogan-tek-partizihniyeti-ve-darbeci-kafa-ayni-madalyonun-iki-yuzu-gibidir/1307552. 2010 yılı Anayasa değişikliği, askeri vesayet ve demokrasi üzerine Erdoğan ile yapılan bir söyleşi için; https://www.ntv.com.tr/turkiye/erdogan-hayir-diyen-darbecidir,bQHGDGasykazMmycFR3roA 8 Levent Köker (2007, s.15-18), Osmanlı'da var olan devlet İslam'ı ve halk İslam'ında demokratik kültür ögelerinin olmadığını belirtir. Benzer şekilde Batı'da halk tabanından iktidara bir başkaldırı olarak ortaya çıkan Batı demokrasisi, Sünni İslam geleneğindeki iktidara boyun eğme geleneğinden hareketle Türkiye' de henüz gerçekleşememiştir. Ayrıca reform hareketlerinin entelijansiyanın öncülügüünde demokrasiye izin vermeyen bir kültürü radikal bir şekilde değiştirmeye çalışırken iktidar-halk arasındaki yeni ilişkiyi tesis eden yapıların olmadan pratiğe dönüştürme çabası toplumsal gerilimlere neden olmuştur. Son olarak Batı demokrasisinin kurucu gücü olarak düşünülen burjuva sınıfının Türkiye'de siyasal iktidar tarafından geliştirilmesi demokrasinin kurumsallaşması bakımından olumsuz olarak nitelenir. Benzer şekilde Metin Heper (2000, s.78), Türkiye'de demokrasinin hala sağlamlaşamamasının nedenlerinden biri siyasi, ekonomik ve sosyal gücün tek bir yetkede toplandığı Osmanlı' nın mirası olan sivil toplumun yokluğudur. Şerif Mardin'e göre (1991, s. 276), modern bir yönetim biçimi olan demokrasinin Türkiye'de kurumsallaşması çabalarının toplumsal alandaki uygulamalarının başarısızlığa uğramasının asal nedenlerinden biri toplumun elitsizleşmeye (de-elitization) başlamasıdır. İlkin Demokrat Parti ile başlayan bu süreç, zaman içinde Türk toplumunun Anadolulaşması ile sonuçlanmıştır. Tüm bunlara ek olarak Bernard Lewis, ylllar boyu otoriter geleneklerin olduğu bir yerde ve hatta otoriteye itaat etmenin dini zorunluluk olarak görüldüğü bir siyasal kültürde özgür kurumların oluşmasının oldukça zor olduğunu belirtir. Türkiye'de demokrasi mücadelesi böyle bir siyasal, toplumsal ve kültürel gelenekten geldiği için sürekli müdahalelere uğrar. Ancak Lewis (1994, s.49), Türkiye'nin kültürel ve toplumsal alanda yaşanan gelişmelere koşut ekonomik ve siyasal alanda da değişimlere uğradığını belirterek Türkiye' de demokrasi mücadelesinin kesintilere uğrayıp geciktirilmesinin söz konusu olabileceğini ancak bu sürecin tersine çevrilemeyeceğini düşünür.
} 
çoğunluğun kararlarının tek bir yetkede toplanması imkân dâhilinde olabilir. Nitekim demokrasinin ne anlama geldiğini bilmeyen, özgürlükleri için mücadele etmeyen bireylerin oluşturduğu toplumlarda içselleştirilmeyen demokratik öğreti, siyasal erkin belirlediği sınırlar çerçevesinde çeşitli anlam erozyonuna uğrar. Keza Jean Werner Müller de demokrasinin içinde bulunduğu tehlikeyi demokrasiyi tehdit eden otoriter bir anlayışın tepkisinden gelmediğini temsili demokrasiyi bir kenara bırakıp doğrudan demokrasi vaadi sunan popülist bir yaklaşımın potansiyelinde bulduğunu söyler. Diğer bir deyişle, demokrasiyi yok edebilecek potansiyel doğrudan demokrasinin kendisini bir araç olarak kullanan siyasal akıldan gelir (Müller, 2016, s.4). Bu bağlamda iktidarın popülist tavrı ve ileri demokrasi söylemleri ile Jean Bodin'in on altıncı yüzyılda egemenliğin tanımını yaparken siyasal iktidarın yanında yer almayanlar üzerinde kurulan tahakküm arasında bir koşutluk kurulabilir: "Cumhuriyetteki üyelerin birliği, geri kalan herkesin etkililiğinin bağlı olduğu, tek bir yönetici altındaki birliktir. Bir egemen hükümdar bu yüzden kaçınılmazdır, çünkü cumhuriyetin tüm üyelerini üye yapan onun iktidarıdır" (Bodin'den aktaran Hardt ve Negri, 2003, s.119). Günümüzde bu bakış açısı, iktidarın kendi meşruiyetini ilan ettiği, ileri demokrasinin temel göstergelerinden sayılan çoğunlukçu anlayışa gönderme yapan yüzde elli artı bir söylemleri ile ben ve öteki ayrımını keskinleştirip kendinden olmayanlar üzerinde baskı kurmaya başlar. Bu durum demokrasinin en temel argümanlarından birisi olan azınlıkların hakkı tezini yok sayıp giderek otoriteryan bir yönetim biçimine doğru evrilir. ${ }^{9}$

Bu siyasal otorite ve toplum arasındaki ilişkinin yön değiştirmesini sağlayan asal nedenlerden biri de ekonomik yönetim biçimlerinde meydana gelen değişimlerdir. Nancy Fraser, bu durumu neoliberal hegemonyanın çöküşü ile ilişkilendirip günümüzde meydana gelen siyasi ayaklanmaların ve tepkiselliklerin temelinde finansallaştırılmış

\footnotetext{
9 Bodin'in egemenlik anlayışı ile günümüz popülist otoriter yönetim biçimi arasında kurulan ilişki günümüz konjonktürü içinde değerlendirilmelidir. Çünkü Bodin, kendi egemenlik teorisini kurarken feodal yapıdaki çoklu güç odaklarının egemenlik anlayışını zayıflattığını belirtir. Bu nedenle egemen gücün sürekliliği ve bölünmez bütünlüğü gücün tek bir nokta toplanarak merkeziyetçi bir yapıya evrilmesi ile mümkündür. Ancak Bodin'e göre bu, farklı şekillerde olabilir. Örneğin egemenlik, azınlıkta ya da bir kişide toplanabilir. Böylece devletin tek egemen gücü olacaktır. Günümüz perspektifinden Bodin'in egemenlik anlayışına baktığımızda cumhuriyetin kuruluş aşamasından günümüz siyasal otoritesine kadar elit olarak nitelenen -genellikle muhafazakar demokrat kesimin işaret ettiği- azınlığın belirlediği demokrasi ve egemenlik anlayışı -bu durum 1960 sonrası anayasa ile halkın çoğunluğunun belirlediği egemenlik anlayışına evrilmiştir- ile yönetilen Türkiye, 2002 sonrası siyasal iktidarın tek bir kişi ile bağlantılandırılarak egemenliğin sürekliliğinin sağlanabileceği vurgusu ile yönetilmektedir. Bu durum Bodin'in merkeziyetçi egemenlik anlayışı düşüncesinin günümüzde de devam ettiğini gösterir.
} 
kapitalizmin yarattı̆̆1 yapısal krizin olduğunu öne sürer. Dünyada eş zamanlı gerçekleşen isyan, ayaklanma ve gösterilerin ortak hedefi, ideoloji ve amaç bakımından farklılaşsa da finans kapitali teşvik eden siyasal iradeye bir tepki olarak okunabilir (Fraser, 2017a). Sosyal ve ekonomik konumlarını kaybetme tehlikesi altında yaşam mücadelesi veren bireyler 'ilerici neoliberalizm'e tepkilerini ortaya koyarak geleneksele dönüş için imkan yaratma potansiyeli olan otoriteryanizme destek verir. Günümüzde neoliberal politikaların kurumsallaşmasının başat nedenlerinden biri olan otoriter yönetimlerin halkın desteğini alabilmesi çelişkili olarak görülebilir ancak konu ile ilgili Fraser, kitlelerin neoliberalizmden ziyade ilerici neoliberalizmi reddettiklerini belirtir. Çünkü son y1llarda yeni toplumsal hareketlerin (feminizm, LGBT, çokkültürcülük vb.) hizmet sektörüne dayalı küresel kapitalist sermayenin ana aktörleri (Hollywood, bilişim sektörü, vb.) ile ittifak kurması sonucu oluşan yeni finansal ortam özellikle üretim sektöründe çalışan orta sınıfları zor durumda bırakır (Fraser, 2017b, s.60). Ancak Türkiye perspektifinden bir okuma yaptığımızda salt ekonomik göstergelerle kitle davranışını anlayabilmek daha zor görünüyor. ${ }^{10}$ Zira Doğu ve Batı kültürünün ayrım noktaları üzerine inşa edilen popülist söylemler kimi zaman halk tabanından destek alırken kimi zaman eleştirilebiliyor. Bu bağlamda halk ile lider arasında kurulan bağın din, milliyet, kültür gibi birden fazla bileşeni olduğu söylenebilir. ${ }^{11}$

\footnotetext{
${ }^{10}$ Her ne kadar ekonomik göstergelerin siyasal iktidarın tek belirleyici etmeni olmadığını söylesek de ekonominin gelişmesi ve halkın refah seviyesinin artması iktidarın sürekliliğini sağlayan temel unsurlardan biridir. Lisel Hintz, 2001 yılında ekonomik krizden kurtulan halkın, istikrarsız koalisyon hükümetlerinin ekonomiyi yönetememesinden bıktığını söyler (Hintz, 2015, s. 4). Özellikle 2002 yılından sonra ekonomideki gözle görülür gelişmeler halkın alım gücünü artırarak siyasal iktidarın her seçimi kazanmasında önemli bir etkendir.

11 Türkiye' de yaşanan ekonomik krizlerin ve giderek artan otoriter yönetim biçiminin halk tarafından hala desteklenmesi ekonomik determinist bakışla açıklanabilecek bir durum değildir. Zira özellikle Erdoğan'ın başarı ile uyguladığı popülist stratejiler ve bunların ana akım medya kurumlarının halka belirli bir perspektiften aktarılması halkın dışsal gerçekliği, popülist bir dil üzerinden inşa etmesine neden olur. Aynı şekilde ekonomik göstergelerin reel toplumsal yaşamda negatif etkileri olsa bile ülkenin fiziksel değişimi -yeni havalimanı, otoyollar, üniversiteler, camiler, alışveriş merkezleri, köprüler vb.- uygulanan politikaların başarılı olduğunu gösterir (Daragahi, 2018). Toplumsal desteğin diğer göstereni kimlik politikaları üzerinden şekillenir. Aslı Aydıntaşbaş, siyasal iktidarın popülist söylemlerinin seçkinler ve halk arasında yaratılan ikilik üzerinden belirlendiğini ve geçmişte seçkinlerin sahip olduğu iktidarın halk tabanında olumsuz sonuçlar doğurduğu üzerinden bir politika yürütüldüğünü söyler. Bu durum seçkinlerin elinden alınan iktidar vasıtasıyla halk ile halkın içinden gelen Erdoğan'ın kimliğini bütünleştirir (Kingsley, 2016). Popülist dini söylemler üzerinden yaklaşıldığında 2013 yılında Reyhanlı'da yapılan saldırıda ölen vatandaşlar için Erdoğan'ın yaptığı açıklama önemlidir: “Reyhanlı' da 53 Sünni vatandaşımız şehit edildi". Sünni ve şehitlik kavramları üzerinden kutuplaştırıcı ve kutsallaştırıcı bir dilin kullanılması çevresel aktörlerin tehlikelerine karşı otoriter güçlü bir iktidarın varlığına duyulan ihtiyacı körükleyebilir.
} 


\section{Gerici Toplumsal Tepkiler}

Son ylllarda giderek artan toplumsal tepkisellik bireylerin seslerini meydanlarda duyurması şeklinde değil daha çok siyasi alanda verdikleri reaksiyonla ölçülmektedir. Konu ile ilgili Karl Polanyi'nin kapitalist ekonomik modelin gelişme aşamasındaki incelemeleri toplumsal reaksiyonların kaynağı konusunda önemli bir veri sunar. Polanyi'ye göre “1879'dan 1929'a kadar geçen yarım yüzyılda, Batı toplumları yıkıcı gerilimler içeren sıkı sıkıya kenetlenmiş birimler oluşturdular. Bu gelişmenin en önemli kaynağı, piyasa ekonomisinin kendi kurallarına göre işleyişinin yıpranmasıydı. Toplum piyasa mekanizmasının ihtiyaçlarına göre düzenlenmiş olduğu için, bu mekanizmanın işleyişindeki aksaklıklar sosyal bünyede giderek artan gerilimlere yol açtı" (Polanyi, 2010, s.276). Polanyi'nin ekonomi-toplum arasında kurduğu bu ilişki, iki yapı arasında var olan denge mekanizmasının bozulması nedeniyle toplumun kendini korumak için verdiği tepki olarak okunabilir. Özellikle İkinci Dünya Savaşı sonrası ortaya çıkan sosyal devlet olgusu ile rahatlayan toplumsalın yeni ekonomi politikalariyla birlikte güvencesizleştirilmesi, mülksüzleştirilmesi ve özelleştirme programlarıyla kamu harcamalarının azaltılması siyasal iktidar ile halk arasındaki gerilimi açıklayabilir. Ancak Türkiye üzerinden toplumsalın tepkisi incelendiğinde reaksiyonun gerici bir perspektifte cereyan ettiği söylenebilir. Çünkü geçmişten bugüne modernleşme tahayyülü nedeniyle temsil edilmeyen ve/veya göz ardı edilen belirli bir sosyal grubun elitist bakışa karşı temsil hakkını bir lider vasıtasıyla kazanabileceği arzusu ile siyasal iktidarın toplumsal özgürleşme ve tüketim olanaklarının artışı gibi popülist söylemleri bir noktada kesişir. Bu bağlamda kitlelerin lider arzusu, belirli temsil mekanizmaları -dini, milli ve kültürelüzerinden şekillenir. Liderin toplumsal çoğunluğu temsil etmesi, aynı zamanda, onların görüşlerine saygı duyması ve onlara yönetimde söz hakkı vermesi üzerinden de güçlendirilir. ${ }^{12}$

\footnotetext{
12 Siyasal iktidar söylemlerini sürekli milli irade, halk oylaması gibi unsurlar üzerine inşa eder. Bu bağlamda doğrudan olmasa da dolaylı olarak halka her seçimde fikirleri sorularak onların görüşü alınıyor ve fikirlerine sayg1 duyuluyor imaj1 yaratılır. https://www.tccb.gov.tr/haberler/410/74834/mill-iradeyeherkesin-saygi-duymasi-lazim.html. Konu ile ilgili Armağan Öztürk, popülist siyasal iktidarın ideolojik kaynağının halka egemenliği nosyonunda yattığını belirtir (2015, s.16). Halk egemenliği kavramı, bu noktada, önem arz eder. Halkın egemenliğine yapılan vurgu ileri demokrasi anlayışının temelinde halkın sözünün geçtiğine vurgu yapar ve sürekli halkın seçimine saygı duyulması gerektiği dile getirilir: "Bu ülkede artık çetelerin, mafyanın değil, bu ülkede artık milletin sözü geçiyor. Bu ülkede artık seçkinler değil, benim milletimin, kardeşlerimin sözü geçiyor." http://www.hurriyet.com.tr/gundem/basbakanin-notlariipadde-17737311. "Halk oylamasında vatandaşımızın kullanacağı oy hangi yönde olursa olsun saygındır, muteberdir. Aslolan milletimizin iradesidir, tercihidir, kararıdır. Kimse milletin kararını küçümseyemez,
} 
“Türkiye'nin küresel dünyada söz sahibi olabilmesi, Batı kültüründen ziyade kendi geleneği üzerinden inşa edilen bir yapı ile mümkün olabilir" düşüncesi günümüz siyasetini belirleyen ana omurgadır. Osmanlı'nın cihan imparatorluğu imgesi ile günümüz Türkiye'sinin küresel dünyanın ana aktörü olma tahayyülü arasında kurulan koşut yapı, bu bakış açısını topluma medya kanalları ile inşa etmeye çalışır. Böylece geçmişin büyüklüğüne duyulan nostaljik arzu günümüzde Yeni Osmanlı anlayışıyla tekrar yaşanabileceği duygusu halka hissettirilir. ${ }^{13}$

Demokrasinin içinde bulunduğu krizin diğer göstergelerinden biri de Türkiye' de özellikle kamusal alanda temsil edilmeyen bireylerin görünürlüğünün sağlanması sonrası ortaya çıkar. Türkiye'nin modernleşme sürecinde laisizmin yanlış anlaşılması ve/veya bilinçli çarpıtılması, ben ve öteki kutuplaşmasının din olgusu üzerinde yapılanmasına neden olur. Bu durum, temelde, modern seçkinlerin İslami kesimi öteki konumuna indirgediği ve halkı, modern seçkin azınlığın belirlediği koşullar çerçevesinde yaşamaya zorlandığı düşüncesine dayanır. Bu bakımdan ülkenin Batı'ya entegrasyonunu sağlayıcı politikaların 'halk için halka rağmen' anlayışından 'halk için halkla beraber'e dönüşmesi ile popülist söylemlerin artışı arasında kurulan koşut ilişki yaşadığımız dönemi anlamlandırabilmek adına önemlidir. Zira yapılan akademik çalışmalar, çoğunluğun desteğini arkasına alarak yürütülen popülist politikaların genelde finansal kapitalizmin dolaylı bir sonucu olan göç hareketleri ve ülkeyi tehdit eden unsurlar -ülkedeki ekonomik krizi yaratan dışsal etmenler, demokrasiye karşı

sorgulayamaz, hor göremez. Herkese düşen aziz milletimizin tercihine saygılı olmaktır." https://t24.com.tr/haber/erdogan-oy-hangi-yondeolursa-olsun-saygindir-muteberdir-ankara-aa, 97547

${ }_{13}$ Konu ile ilgili yapılan açıklamalardan örnekler: "Bizim ecdadımız ürkek olmadı; biz de ürkek olmayacağız. Türkiye bölünecek diye etrafa korku salanlara inat cesaretle geleceğe yürüyeceğiz" (https://twitter.com/rt_erdogan/status/309308978544930816); “'Kızılelma'sını arayan ecdadımız, Ertuğrul Gazi ile kendisine yeni bir istikamet belirlemiştir... Bugün Türkiye olarak biz de aynı yoldan gidiyoruz" (T24 Gazetesi, 09 Eylül 2018); "Biz merhamet dininin mensuplarıyız. Bizde azap yok, bizde zulüm yok. Bizim ecdadımız da öyleydi. Hint Yarımadası'na ecdadımız kadırgalar gönderdi, bir kişinin kurtuluşu için. Böyle bir ecdanın torunlarından zulüm beklenir mi?... Şunu bilin biz seferle emrolunduk, zafer Allah'a aittir” (Sabah Gazetesi, 07 Mart 2018); “Uzunca bir süre ecdadın ihtişamlı medeniyet mirasına sırtımızı dönüp kendimizi her alanda gecekondulara, kaçak yapılara mahkûm ettik. Türkiye'nin yeni Mehmet Akif'lere, Tanpınar'lara, Necip Fazıl'lara, Nâzım Hikmet'lere, Arif Nihat Asya'lara, Kemal Tahir'lere ihtiyacı var" (Milliyet Gazetesi, 20 Aralık 2018); "Esasen bizim ecdadımız, yıllarca kendi döneminin teknolojilerine öncülük etmiş, daha sonra liderliği ne yazık ki elinden kaçırmıştır. Osmanlı Devleti 17. yüzyıldan itibaren teknoloji konusundaki geriliğinin farkına varmıştır. Dönemin padişahları ve dirayetli yöneticileri bu sorunun çözümünü batının teknolojisini ülkemize taşımakta görmüştür... Hezarfen'in, Ali Kuşçu'nun, Uluğ Bey'in başlattıkları hamleyi işte bu gün burada yeni havalimanımızda çok farklı bir yere taşıyoruz" (Cumhuriyet Gazetesi, 22 Eylül 2018). Görüldüğü üzere söylemler genellikle Osmanlı, din ve büyüklük teması çerçevesinde şekillenir. 
gerçekleştirilen eylemler vs.- üzerinden yürütüldüğünü gösterir (Plattner, 2010; O’Donnell, 2018; Pühringer ve Ötsch, 2018; Bozkurt, 2013; Visvizi, 2017).

Parlamenter demokrasinin siyasal alanda yaşattı̆̆ istikrarsızlıklar ile ekonomik kriz arasında kurulan bağıntı toplumun çıkarları ile ters düştüğü ve devlet-toplum arasında bir temsil krizi yaşandığı için kimi zaman toplum gerici reaksiyonlar vererek kendi özgürlük alanını daraltma yoluna gider. İnsanın bu pragmatist tavrı dünya genelinde yaşanan göç hareketleri ile birlikte gözlemlendiğinde özgürlük istemlerinin ${ }^{14}$ yaşamsal dürtülerin geri planında kalarak yerini güvenliğe bırakması olarak okunabilir. $\mathrm{Bu}$ bakımdan gerici popülist söylemlerin beslendiği diğer kaynak da güvenlik politikalarının artırılması talebinden doğan özgürlüğün reddidir. Özgürlüğün istemli yadsınmasında medya araçlarından üretilen dezenformasyonun rolü büyüktür. Medyanın gerçekliği iktidar perspektifinden yaratması siyasal iktidarın egemenlik arzusunun simgesel zor ve şiddet kullanarak öteki üzerinde kurduğu üstünlüğü gösterir. Böylece çoğunluğun egemen, ötekilerin çoğunluğa bağlı kılındığı bir sistem ortaya çıkar (Hardt ve Negri, 2003, s.119). Özgürlük ve güvenlik paradoksu, günümüz hakikat sonrası çağda soyut kavramlar üzerinden tekrar gündeme gelir. Medya araçları kullanılarak halkın manipüle edilmesi sağlanıp ben ve öteki ikiliği keskinleştirilir. İki karşıt uç arasındaki gerilim ulusal ya da uluslararası problemlerin ekonomik, siyasal ve toplumsal bağlamda öteki ile nedenselleştirilerek üretilmesiyle artar. ${ }^{15}$ Özellikle hakikatin medya araçları vasıtasıyla belirsizleşmesi, 2016 yılında İngiltere'nin Avrupa Birliği'nden çıkmasına karşılık gelen Brexit oylaması sürecinde üretilen yalan haberlerde görülebilir. Örneğin, kampanya sırasında Avrupa Birliği'ne haftada 350 milyon Pound gönderildiğini, bunun yerine Ulusal Sağllk Sisteminin finanse edilmesini isteyen ekonomi ile veya Türkiye'nin Avrupa Birliği'ne gireceğini ve milyonlarca göçmenin ülkeye geleceğini iddia eden toplumsal sorunlarla ilgili doğru olmayan ${ }^{16}$, ancak toplumsal öfkeye neden olan haberler günümüz siyasetinin belirleyici unsurlarıdır.

\footnotetext{
${ }^{14}$ Sigmund Freud (2014, s.7), "insanların çoğu özgürlüğü gerçekten istemezler; çünkü özgürlük sorumluluk gerektirir ve insanların çoğu da bundan korkar" derken günümüz liberal demokrasilerinin içinde bulunduğu krizi insan davranışları üzerinden özetler. Zira insan, Immanuel Kant’ın belirttiği üzere özgür olmak yerine "ergin olmama durumu" içinde kalmayı arzular. İnsanın kendi aklını başkasının kılavuzluğunda kullanması, sorumluluktan kaçmayı ve zahmetsiz yaşamayı sağladığından eylem ile eylemsizlik arasında sıkışan insan, genellikle özgürlük isteminden taviz verir (1984, s. 213).

${ }_{15}$ Burada Ben ve Öteki kavramları Türkiye'de yaşayan farklı görüşte insanlar, gruplar, cemaatler veya Türkiye'nin uluslararası platformda gelişmesini, büyümesini istemeyen diğer ülkeler üzerinden inşa edilebilir. Dezenformasyon, medya ve siyaset arasındaki ilişkiyi hakikat sonrası çağda tartışan çalışma için Bkz. Corner, J. (2017).

${ }^{16}$ https://www.bbc.com/news/uk-politics-eu-referendum-36574526
} 
Türkiye'de de özellikle medyanın tekelleşme eğilimleri sonucu ve siyasal iktidar ile ilişkileri bağlamında haber üretimindeki nesnellik olgusuna yaklaşıldığında benzer problemlerin varlığı dikkat çeker. Reuters Enstitüsü'nün hazırladığı 2018 Dijital Haber Raporu'nun dezenformasyon konusunda 37 ülkede yaptığı araştırmanın sonucuna göre Türkiye yüzde 49 ile en çok dezenformasyona maruz kalan ülke olarak açıklandı.. ${ }^{17}$ Hakikat sonrası çağda doğru bilgiye ulaşabilmek için teyit.org ve oyveotesi.com gibi çeşitli gönüllü kuruluşların toplumsal ve siyasal gerçeklik bilincimizi yeniden tesis etmeye çalışması da yapılan araştırmanın doğruluğuna destek sağlar. Bu bağlamda günümüz popülist politikalarının kültürel egemenlik arzusunu yeniden inşa etmeye çalışmaları demokrasinin daha üst bir seviyeye taşınmasından ziyade totaliter bir zemine oturduğunu gösterir. Zira popülist söylemlerle çoğunluğun desteğini arkasına alan siyasal iktidar, ekonominin dışa bağımlılığı göz önünde bulundurulduğunda, kriz yönetimini geçici çözümlerle gidermeye çalışır. Bu noktada doğanın bir yatırım alanı olarak sermayeye sunumu iki açıdan iktidara yarar: Halka hizmet ediyor görünmek ve sermayeyi beslemek.

Konu ile ilgili en çarpıcı örnek olarak üçüncü havalimanı projesi gösterilebilir. Ulaştırma Bakanlığı tarafından Yap-İşlet-Devret modeli ile 3 Mayıs 2013'de ihale edilen proje Cengiz, Kolin, Limak, MAPA, Kalyon Ortak Girişim Grubu tarafından alınmıştır. “Proje alanının 6.173 hektarı orman, 1.180 hektarı madencilik ve geri kalanın 660 hektarı göl, 236 hektarı mera, 60 hektarı tarım, 2 hektarı fundalıktır. Etki sahasındaki kesimler dahil edildiğinde yaklaşık olarak 2,5 milyon civarında ağaç kesimi yapılacağı öngörülmektedir" (TMMOB İstanbul İl Koordinasyon Kurulu 3. Havalimanı Teknik Raporu, 2014, s.2). Türkiye'de dünyanın en büyük havalimanı projesi olan İstanbul Havalimanı'nın ulusal güç gösterisi, büyüklük çerçevesinde yapılandırılırken bölgede oluşabilecek çevresel zararın gelecekte oluşturabileceği problemleri göz ardı edilir. Ormanlık alanın ve sulak bölgelerin tahrip edilmesi bölgedeki ekosistemin değişmesine neden olabileceği gibi yeni yaşam alanlarının göç ile birlikte kuzeye doğru genişlemesi de mümkündür. Bu bakımdan projenin birden fazla sorunu beraberinde getirebileceği görülebilir. Konu ile ilgili Bayrakdar ve Durmaz, havalimanının gürültü, hava ve su kirliliği, atık ve enerji yönetimi, yaban hayatı konusunda olumsuz etkileri olacağını belirtir. Zira havalimanının inşa edildiği bölge tarım alanı, çayırlar, göçmen kuşların geçiş yolu gibi farklı çevresel zararları içinde barındırır. Özellikle göçmen kuşların

\footnotetext{
17 https://reutersinstitute.politics.ox.ac.uk/sites/default/files/2018-11/Digital\%20News\%20Report\%20\%20Turkey\%20Supplement\%202018\%20FINAL.pdf
} 
gürültüden ve yiyeccek-içecek su kaynaklarının yok olması nedeniyle birçoğunun türlerinin yok olacağını öngörürler. Aynı zamanda hava kirliliği ve iklim değişikliği gibi sorunların da gelecekte yaşanabileceğini tahmin ederler (2014, s.772-774). Yapılan çalışmalar ekosistemin en önemli unsuru ormanların iklim ${ }^{18}$ üzerinde etkili olduğunu göstermektedir (Kırış ve Toprak, 2009, s.383). Ancak havalimanının bu yapısal etkilerinden ziyade popülist söylemlerle ulusal kimliğe yapılan vurguları dikkat çeker. 7 Haziran 2014 yılında dönemin Başbakanı "3. Havalimanı, 6 pisti ve yıllık 150 milyon yolcu kapasitesi ile dünyanın en büyük havalimanı olacak"19 şeklinde yaptığı paylaşımla, salt büyüklüğe bir vurgu yapar. Benzer şekilde ana akım medyada da havalimanı projesinin ülkeye katacağı faydalar sıralanır.

\section{Bir Yatırım Aracı Olarak Doğa}

Farklı yönetim sistemlerinde neredeyse eş zamanlı patlak veren krizler ve otoriterleşme eğilimi, yaşananların salt ekonomik, siyasal ya da toplumsal krizin ötesinde bir çeşit modernlik krizi olduğuna işaret eder. ${ }^{20}$ Donald Trump'ın ABD başkanı olarak seçilmesi, Birleşik Krallık'ın Avrupa Birliği üyeliğinden ayrılması yönünde çıkan karar ile birlikte dünya genelinde aşırı sağın giderek yükselmesi gibi olaylar popülist üslubun halk tabanında karşılık bulduğunu gösterir. Aynı şekilde Hindistan, Endonezya, Türkiye, Macaristan, Rusya, İsrail gibi farklı coğrafyalardaki ülkelerde de popülist otoriter yönetim tarzının uygulandığını söylemek mümkündür. ${ }^{21}$ Zira popülizm Benjamin

${ }^{18}$ Doğa tahribatı ile iklim değişikliği arasında kurulan doğrusal ilişki yakın zamanda mevsim değişikliği, aşırı yağış miktarı gibi doğa olaylarının sık yaşanmasına neden olur. Son yıllarda artan aşırı yağmur ve sel felaketleri ile aşırı sıcak nedeniyle oluşan kuraklık iklim değişikliği probleminin ilk uyarılarını verir. Örneğin, 2009 yılında İstanbul'da gerçekleşen sel felaketi yüz yılda bir olan doğa olayı olarak medyada yer bulurken benzer bir doğa olayı 2013 yılında tekrarlanmıştır. En son 2017 yılında gerçekleşen sel felaketi, yüz yılda bir olan doğa olaylarının günümüzde daha sık periyotlarla gerçekleştiğini işaret eder (Hürriyet, 9 Eylül 2009; Hürriyet, 14 Haziran 2013; Sözcü, 28 Temmuz 2017).

${ }^{19} \mathrm{https} / /$ twitter.com/rt_erdogan/status/475296968009609216

${ }^{20}$ Burada modernlik krizi derken modernliğin sonu gibi bir anlam çıkarılmamalıdır. Modern anlayış kimi zamanlarda ekonomik, siyasal ve toplumsal çeşitli krizler yaşamış ve bunu çeşitli politikalarla atlatmıştır. Günümüzde de buna benzer bir durum söz konusudur. Örneğin, siyasal otorite krizi ile ilgili dört farklı modern siyasal model denendiğini belirten Gerard Delanty'in "Europe in the Short Twentieth Century: Conflicting Projects of Modernity" (2019) isimli çalışması yaşanan siyasal krizi anlamlandırmak için yol gösterebilir. Devlet sosyalizmi, faşizm, liberal demokrasi ve ulusötesi yönetim modeli olmak üzere dört farklı modern siyasal yönetim modelini tartışan Delanty, ilk iki modelin başarısızlıkla sonuçlandığını belirtir. Günümüzde liberal demokrasinin Avrupa'da kısmen başarılı olabildiğini, bu nedenle ulusötesi bir yönetim tarzına evrildiğini söyler (s. 268, 300).

21 IPSOS'un yaptığı araştırma, dünyada popülizmin çoğunluğu etkilediğini göstermektedir. Farklı coğrafyalarda yer alan yirmi beş ülkede yapılan araştırmada ankete katılan yüzde 52'lik kesim geleneksel 
Moffitt'e göre tekil bir varlık değil, farklı politik ve kültürel bağlamlarla gerçekleştirilen, somutlaştırılan ve benimsenen politik bir tarzdır (Moffitt, 2016, s.3). Bu nedenle bir siyasi rejime veya sabit bir ideolojik içeriğe indirgenemez (Taguieff'den aktaran Bezmez, 2018). Ancak popülist söylemlerin belirli bir ortak noktada buluştuğu -dini, milli değerler vb.ve kitleleri konsolide etmeye çalıştı̆̆ söylenebilir. ${ }^{22}$ Bu ortak noktalardan biri de Anthony Giddens'ın Modernliğin Sonuçları (2012, s.70) adlı yapıtında belirttiği küreselleşmenin boyutlarından endüstriyel gelişmelerle ilgili bireyin maddi çevreyle ilişkisini doğrudan değiştiren yatırımlardır. Popülist liderlerin halk ile doğrudan temas kurdukları ve onlara hizmet olarak sundukları bu yatırımlar²3, Ben ve Öteki karşıtlığı üzerinden yürütülen

siyasi partilerden ziyade kuralları çiğneyen güçlü bir lidere ihtiyaç duyduklarını belirtmişlerdir. Avrupa'da insanların siyasal iktidarlara güvensizliği de giderek artmaktadır. İspanya'da yüzde 89, İtalya' da yüzde 80, İngitere'de yüzde 66'lara varan güvensizlik duygusu popülist politikaların giderek artmasında önem teşkil etmektedir. Bu durum göstermektedir ki parlamenter siyasal sistemin temsil mekanizmasında belirli sorunlar olduğundan halk kendisini temsil eden güçlü liderlere ihtiyaç duymaktadır (https://www.ipsos.com/en/beyond-populism-two-years-after).

${ }^{22}$ Dünyadaki popülist liderlerin söylemleri incelendiğinde belirli ortaklıklar bulmak mümkündür. Trump, 45. ABD Başkanı olarak açılış konuşmasında ilkin milli iradaye atıfta bulunur: "20 Ocak 2017, halkın tekrar bu ulusun hükümdarı olduğu gün olarak hatırlanacak". Konuşmanın devamında doğrudan İncil'den referanslar verir: "İncil bize, insanların birlik içinde yaşamasının ne kadar iyi ve hoş olduğunu söylüyor." Son olarak konuşmasını "Amerika'yı yeniden muhteşem yapacağız. Tanrı ve Amerika'yı sizi korusun" sözleriyle bitirir (https://www.whitehouse.gov/briefings-statements/the-inaugural-address). Benzer şekilde Erdoğan'ın söylemleri aynı kavramlar üzerinden ilerler: "Bu millet asker bir millettir", "Biz şu veya bu gücün ne dediğine değil, sadece ve sadece Allah'ın ne dediğine baktık, sadece ve sadece milletimizin ne dediğine baktık. Türk milleti olarak daha dünyaya son sözümüzü söylemedik" (https://www.tccb.gov.tr/receptayyiperdogan/konusmalar). Fransa'nın aşırı sağ popülist lideri Marine Le Pen'in söylemlerine bakıldığında da benzerlikler bulmak mümkündür. Le Pen, İslam'ın laikliğe aykırı bir din olduğunu belirterek Müslüman karşıtlı̆̆ını meşrulaştırmaya çalışır. Göçmen politikalarının halka zarar verdiğini düşünen Le Pen, yabancı işçilerin Fransa'da yerel halktan daha iyi durumda olduğunu öne sürerek herkesin ülkesine dönmesi gerektiğini vurgular. Zira göçmenler milli kimliği bozan, tehlikeli kişiler olarak betimlenir (Saç, 2017, s.281, 282). Hindistan'da Narendra Modi'nin popülist politikaları ise milli ve gayri millilik kavramları üzerinden ilerler. Modi'nn diğer popülist liderler ile en önemli benzerliği kendisini meşru sayarken muhalifleri ya da kendi görüşünü benimsemeyenleri meşru görmemesinde yatar. Zira Modi'ye göre muhalifler ülkeyi bölmek isteyen, milli olmayan kişilerdir. Bu nedenle Hindistan'daki entelektüeller, muhalif akademisyenler gayri milli olarak nitelenir (Telek, 2017).

${ }^{23}$ Cumhurbaşkanı Erdoğan halka yaptığı bir konuşmada "Batı bizi niçin kıskanıyor" diye sorduktan sonra cevaplarını şu şekilde sıralar: "İşte bu barajlardan dolayı kıskanıyor. Yavuz Sultan Selim Köprüsünden dolayı kıskanıyor. Boğazın altından geçen Marmaray Tünelinden dolayı kıskanıyor, metrosundan dolayı kıskanıyor. Bak üç sene oldu, üç senede ne kadar insan geçti oradan biliyor musunuz? 130 milyon insan geçti, 130 milyon. Bitmedi, yıl sonuna kadar Avrasya Tüneli bitiyor, oradan da otomobiller geçecek. Geçenlerde gittik, Körfez Geçişi Osman Gazi Köprüsü’nün son tabliyesinin vidalarını sıktık. Yani bir nevi kaynağını attık ve oradan da Orhangazi'ye kadar 40 kilometrelik otoyolun açılışını yaptık." https://www.tccb.gov.tr/haberler/410/43999/bu-topraklar-uzerinde-gozu-olanlar-bedelini-cok-agiroduyor 
politikalarla hem siyasal hem de çevresel bağlamda meşruiyet kazanır. Ancak yol, köprü, baraj, havaalanı gibi yatırımların giderek artmasının aşırı kentleşmeye yol açarak doğaya verdiği zarar gözden kaçırılmaktadır. Zira modernliğin kurumsal boyutlarından biri olan endüstriyalizm ${ }^{24}$ doğaya -dolayısıyla insanlara- salt çevreye yaydığı gazlarla zarar vermez; aynı zamanda ormanları yok ederek, aşırı kentleşerek de zarar verir. Bu bakımdan doğanın sürekli tahribatı yakın gelecekte insanları küresel ısınma, aşırı hava kirliliği, iklim değişikliği gibi tehlikelerin geri döndürülemeyecek sonuçlarılya karşı karşıya bırakabilir. Bu bağlamda ekonomik pragmatizm, iklim değişikliği ve doğal kaynakların tükenmesi gibi problemler nüfusta hızlı ve oldukça büyük bir boyutta değişikliklere neden olabilir (Dyer, 2013, s. 20). Ancak genellikle günümüzde toplumsal bir problem olarak yansitılan doğudan batıya, güneyden kuzeye göçün iklim değişikliği ile ilişkisi genellikle göz ardı edilir. Hatta günümüzde popülist liderler göçmen karşıtı söylemleri kendi politikalarının bir aracı olarak kullanır. Bu bakış iklimsel problemlerin nereden temellendiğini gözden kaçırmaya neden olur, ve küresel sermayenin yeni yatırım alanları olarak doğanın nesneleştirilmesi olumlanmaya çalışılır. ${ }^{25}$ Zira popülist iktidarların halka hizmet aracı olarak gerçekleştirdiği doğa tahribatları ile iklim değişikliği arasında bir bağıntı olmadığı; hatta iklim değişikliğinin tarih boyunca gerçekleşen bir süreç olduğu iddia edilir (Lockwood, 2017, s.3,4).

NASA'nın yaptığı araştırmalara göre dünyada iklim değiş̧ikliği tarih boyunca çeşitli evrelerde gerçekleşen doğal bir süreçtir. Ancak bu değişim son 200 yıl içinde küresel sıcaklık artışı, okyanusun 1sınması, eriyen buzullar, deniz seviyesinin yükselmesi, okyanusun asitlenmesi gibi birbirini tetikleyen doğal olmayan dışsal müdahalelerin meydana getirdiği tehlikeli bir noktaya gelmiştir. ${ }^{26}$ İnsanlık tarihinde belirli bir dengede süregiden insan-doğa arasındaki ilişkinin son iki yüzyıllık bir zaman

${ }_{24}$ Anthony Giddens, Modernliğin Sonuçları adlı eserinde modernliğin kurumsal boyutlarını dört boyut altında toplar. Bunlar sermaye birikimine dayalı bir ekonomik sistem olan kapitalizm, ulus-devlet siyasal modelinin temelini oluşturan ve kapitalizm ile doğrudan ilişkili gözetleme, "savaşın endüstrileşmesi bağlamında şiddet araçlarının kontrolü"nü sağlayan askeri iktidar ve insanlığın doğa ile etkileşimi belirli bir düzeyde kesen, doğayı rasyonel akıl üzerinden dönüştüren endüstriyalizmdir (2012, s. 56).

${ }^{25}$ Günümüz iklim politikaları iktidar partileri tarafından önemsiz bir detay olarak sunulur. Örneğin, Filipinler devlet başkanı Rodrigo Duerte 2017 yılında imzalanan iklim anlaşmasını saçma olarak değerlendirirken, Brezilya'nın cumhurbaşkanı seçilen Jair Bolsonaro, Amazon ormanlarının korunmasını ile ilgili düzenlemelerin azaltılması gerektiğini belirterek küresel sermayenin kullanımına açarak ekonomik girişimlere izin vermeye çalışır. Ancak bunlara karşın Kanada'da Justin Trudeau'nun sera gazı salınımlarının azaltılması için yürürlüğe koyduğu karbon vergisinin gelecek seçimlerde sıkıntıya neden olabileceği belirtiliyor. Zira Saskatchewan ve Ontario eyaletleri karbon vergisinin ekonomiyi negatif yönde etkilediğini belirterek yasaya karşı tutum aldıklarını belirtirler (Hook, 2018).

${ }^{26}$ https://climate.nasa.gov/evidence/ 
dilimi içinde bozulmaya başlaması modernliğin sonuçlarından biridir. Modern ile geleneksel arasında varolan karşıtlık öncelikle iki kavramın değişim hızı ölçüsünde ayrımsanabilir. Konu ile ilgili Giddens, teknolojik gelişimin modernliğin değişim hızını son derece artırdığını ve diğer bütün alanlara yayıldığını; modern kurumların doğasının özellikle cansız güç kaynaklarına bağımlı olduğunu ve bu nedenle doğanın ve insan emeğinin metalaştırıldığını belirtir (Giddens, 2012, s.13). Bu bakımdan günümüzde yaşanan siyasal krizlerin -liberal demokrasilerin terk edilip totaliter demokrasiye geçişin- popülizm ile ilişkisini anlayabilmek için Aydınlanma ile başlayan insanın özne, doğanın nesne olma sürecinin irdelenmesi gerekir.

On altıncı yüzyılda insan-doğa mücadelesi üzerine Bacon, insanın doğaya yalnızca düşüncede hükmettiğini, bu nedenle onun boyunduruğu altında olduğunu; ancak teknolojinin gelişimi ile birlikte insanın doğaya salt düşüncede değil uygulamada da hükmedebileceğini savunur (Adorno ve Horkheimer, 2014, s.20). Bacon'un erken modernlik döneminde sözünü ettiği doğanın denetim altına alınma tahayyülü endüstriyalizm ile başarılır ve doğa, araçsallaşan insan aklı tarafından tahakküm altına alınır. Bu durum insan aklının olumlanması ve rasyonel bir düşünce seviyesine çıması ile mümkün olmuştur. Diğer bir deyişle, endüstri devrimi sonrası burjuva ahlakı insaninsan ve insan-doğa arasındaki ilişkiyi salt sermaye birikimi perspektifinden belirlemiştir. Böylece Adorno ve Horkheimer'a göre (2014, s.20) insan -homo economicus, doğayı ve insanları tümüyle egemenliği altına almak için doğayı bir araç olarak kullanmaya başlamıştır.

Endüstri Devrimi, doğanın dönüştürülmesi ve yapay bir çevrenin gelişimi açısından modern öncesi sistemlerden ayrılır. Bu yapay çevrenin gelişimi salt insanların yaşadığı konut alanları olarak düşünülmemeli, aynı zamanda kentsel yaşamın olmazsa olmazı fabrikalar, işyerleri, caddeler, parklar, köprüler, ulaşım sahaları gibi modernliğin toplumsal alana yansıyan fiziksel mekanları olarak da düşünülmelidir. Bu ortamların geleneksel yaşamdan farkları bireyin dünyayı 'yapılandırılmış bir mekan' içinde algılamalarıdır. Bireyin dış dünya ile kurduğu etkileşimin doğal olmayan bir süreçte gelişmesi 'yeni bir insan tipinin' oluşmasının ilk basamağıdır. Günümüz modern yaşamında insan davranışlarının ilk örneklerinden birini Tolstoy, Anne Karenina eserinde Stepan Arkadyeviç üzerinden gösterir. Ünsal Oskay, Tek Kişilik Haçl Seferleri adlı eserinde Arkadyeviç örneği üzerinden 'başkalarınca yöneltimli insan'ı günümüz 
insanının davranışlarına uygunluğu çerçevesinde değerlendirir. ${ }^{27}$ Özellikle modern toplumlarda insanlar dış dünyayı hem kendi geçmiş yaşantısı hem de kitle iletişim araçlarından aldığı iletiler dolayımıyla anlamlandırır. Bu bakımdan özellikle liberal demokrasilerde insanların tercih mekanizmalarının istemli ya da istemsiz çoğunluğun tercihine doğru kaydığı söylenebilir. Bu insan davranışını anlayabilmek akademik çalışmalarda otoriter popülist liderlerin söylemlerinin nasıl halk tarafından kabul edildiğini çıkarsamak adına bir yol gösterebilir. Böylece geçmişten bugüne toplumun belleğini oluşturan tarihi eserlerin ve/veya üzerinde yaşanılan coğrafyanın ekolojik dengesinin bozulup toplum için yol, alışveriş merkezi, park, havaalanı gibi çeşitli hizmetlere dönüşmesinin toplum tarafından kabulü ve desteği arasında bir ilişki kurulabilir.

Türkiye'de Adalet ve Kalkınma Partisinin neoliberal popülizmini anlamaya çalışan Umut Bozkurt, partinin oy aldığı sosyal kesimler ile uygulanan geçici ekonomiksosyal yardım programları arasında anlamlı bir ilişki olduğunu ve popülist politikalarını genellikle sosyal yardım programları üzerinden işçi sınıfı, ev hanımı, işsizler ve çiftçiler gibi toplumun farklı kesimlerini birleştirmek için kullandığını; parti ile sağduyu ${ }^{28}$ arasında kurulan ideolojik ilişkinin muhafazakar ve milliyetçi söylemlerle beslenerek kendi hegemonyasını oluşturduğunu belirtir (Bozkurt, 2013, s. 372). Appadurai'ye göre günümüz neoliberal popülizmlerinde lider ve takipçisi arasında kurulan ilişkinin yeniden düşünülmesi gerekir. Geleneksel analiz yöntemlerinde kullanılan karizma, propaganda gibi etmenler artık günümüz için çok da geçerli değildir. Lider ve takipçileri arasında kurulan yeni bağ sürekli bir bütünlükten ziyade kısmi örtüşmelerin olduğu bir yapıdır (Appadurai, 2017, s.18). Buna göre takipçiler, liderin uyguladığı siyasi ve/veya ekonomik politikalara kimi zaman tepki gösterebilir ancak yine liderin uyguladığ1

${ }^{27}$ Oskay'ın (2014, s.265) yeni insan tipini örneklemek için Riesman'dan yaptığı alıntı şu şekildedir: “Stepan Arkadyeviç, öyle aşırı olmayan, çoğunluğun görüşlerini yansıtan liberal gazetelerden birinin meraklısı idi, onu okurdu. Ve bilime, sanata, siyasete, kendine kalsa, pek ilgi de duymazdı; ama, çevresindeki insanların çoğunluğunca beğenilen gazetesinde de tutulduğunu gördüğü görüşlere, bunlar hangi konuyla ilgili olurlarsa olsunlar, inandı mı inanır; çoğunluğun artık bunlara inanmaz olduğunu görünce inanmayı bırakırdı. Daha doğrusu söylemek gerekirse bunlar, değiştiklerini kendisi de pek anlayamadan, öylece değişirlerdi kafasında." Modern toplumsal yaşamın ürettiği yeni insan tipinin şehir yaşamındaki kültürün geleneksel yaşamda olduğu gibi bir bütün olarak değil, parçalanmış kümeler halinde alt kültürlere bölündüğünü ileten Oskay, bireyin her ortamda o ortamın onayını alabilmek için başkalarının onayına ihtiyaç duyduğunu iletir.

28 Burada kullanılan sağduyu kavramı Gramsci'den alınmıştır. Gramsci, hegemonyanın temel unsurlarından birini var olan kültür ile bağlantıların oluşturulması olarak açıklar. Buna göre sağduyu, insanları hakim söylemin belirlediği toplumsal yaşam pratikleri çerçevesinde hareket etmelerini sağlayan ve içselleştiren bir kavram olarak açıklar (Bozkurt, 2013, s.381). 
politikalarla rahatlayabilir ve onu destekleyebilir. Burada dikkat edilmesi gereken nokta, liderin uyguladığı politikaların dönemselleştirilmesi ve güven tesisi ile medya araçlarında sunumudur. Böylece totaliter demokrasinin halk ve sermaye ile kurduğu ilişki, doğanın nesneleştirilmesinin toplum yararına olduğu yönünde kanı yaratır. Birçok düşünür iklim politikalarındaki başarısızlığg demokrasinin başarısızlı̆̆ı olarak görür, hatta demokrasinin iklim değişikliğine karşı yürütülecek politikalar için yetersiz bir siyasal sistem olduğu öngörülür (Kitcher, 2011, s.243). Konu ile ilgili totaliter demokrasilerin doğanın sömürülmesini engellemek için daha olumlu politikalar yürütebileceğini iddia eden düşünürler de vardır (Brown, 2014, s.142). Ancak bu yaklaşım günümüz küresel sermaye krizi ile yükselen sağ politikaları arasındaki bağ1 görmezden gelir. Endüstri devriminden bugüne inorganik üretimin yükselişi (sonucu artan sera gazı salımı vb.) ve küresel sermayenin kendi pazarını artırmak için farklı coğrafyalarda yatırım alanı bulma çabası doğanın sömürüsüne devam edildiğini ve bunun popülist iktidarlar tarafından halkın desteğini alarak gerçekleştirildiğini göstermektedir. ${ }^{29}$ Bununla birlikte halkın tepkisini çeken uygulamaların da sermayeyi beslemek adına devam ettiği söylenebilir. ${ }^{30}$ Burada önemli olan, küresel sermayenin medya aracılığıyla birbirinin tezatı kavramları popülist bir söylemle farklı koşullar içinde haklı gösterebilme becerisidir. Diğer bir deyişle doğa, toplum, gezegen için tehlikeli olan eylemleri, girişimleri 'medya endüstrisi' halk için yapıldığını göstererek ters bir alg1 yaratabilir. Bu durum, içinde yaşadığımız hakikat sonrası çağda gerçekliğin biçimbozumuna uğradığını gösterir. Konu ile ilgili en somut örnek, dünyada en fazla

29 Popülist iktidarların (halk için) yaptı̆̆1 yatırımlar her zaman bölge halkı tarafından desteklenmemektedir: Tortum'daki HES protestosu, Artvin Cerattepe direnişi, Gerze ve Çerkezköy Termik Santral direnişi, Zeytinli Barajı direnişi vb. Ancak yine de bu bölgelerin siyasal iktidar ile ilişkisi seçim sonuçları üzerinden incelendiğinde olumsuz bir tabloya rastlanmaz. Daha önce de belirtildiği üzere popülist iktidar ile halk arasındaki ilişki kişisel çıkarların ayrım ve kesişim noktaları üzerine temellenir. Bu bağlamda halkın tepkisi olumsuz olarak görülse de ekonomik sıkıntılar, medya iletileri, eğitim seviyesi, doğa tahribatı ile failleri arasında kurulmayan bağıntı gibi birçok nedenden dolayı iktidarı olumlayabilir. Bu durum istihdam, işsizlik, modern yaşama uyum sağlama eğilimi gibi birçok fonksiyonu içinde barındıran analiz edilmesi güç, karmaşık bir süreci ifade eder. Konu ile ilgili Soma maden kazası sonrası bölge halkı ve iktidar arasındaki ilişkiyi anlamak için Bkz. Kantaş, Ö. (2015).

${ }^{30}$ Konu ile ilgili, Shell ve Chevron'un Ogoni bölgesinde petrol çıkarırken sızıntıların ve yakılan gazların bölgenin toprakların, nehirlerini tahrip etmesi ve bunun üzerine askeri yetkililerin Nijerya hükümeti tarafından infaz edilen Ken Saro-Wiwa'nın öncülüğünü yaptığı Ogoni Halkının Yaşamını Sürdürmesi Hareketinin (MOSOP) protestolarına şiddetle karşılık vermesi örnek olarak gösterilebilir (Galeano, 2017, s. 173). Görüldüğü üzere neoliberal ekonominin ulusaşırı şirketlere gelişmemiş ülkelerin doğal kaynaklarını kullanma ve tahrip etme hakkı tanıdığı; bunu da o ülkenin otoriter rejimi vasıtasıyla istikrarlı bir biçimde yaptığı söylenebilir. 
kimyasal atık üreten şirketlerinden biri olan DuPont'un, aynı zamanda tehlikeli endüstriyel atıkların gömülmesi konusunda hizmet vermesidir. Aynı şekilde General Electric, dünyayı en fazla kirleten ancak bununla beraber hava kirliliğini kontrol eden cihazların ABD'deki en büyük üreticilerinden biridir (Galeano, 2017, s. 178). Türkiye'de de benzer bir durum mevcuttur. Kütahya'nın endüstriyel yapılanma sonucu hava kirliliğinin insan sağlığını tehdit edecek seviyelere ulaşması; bununla birlikte şehirde iki adet termik santralin bulunması ve özellikle kış aylarında hava kirliliğinin üst seviyelere çıkması bilimsel verilerle ortaya konmasına rağmen herhangi bir düzenleme gerçekleştirilmemiştir (Keser, 2002, s.76, 98). ${ }^{31}$ Zira Türkiye İstatistik Kurumu'nun 20102011 kış mevsimi hava kalitesi istatistiklerinde Iğdır, Osmaniye, Batman, Isparta, Afyon il-ilçe merkezlerinde ve Çevre ve Şehircilik Bakanlı̆̆g'nın Hava Kalitesi Şubat 2019 Bülteninde birçok şehirde sınır değerlerin aşıldığı gözlemlenir. ${ }^{32}$ Hava kalitesinin giderek azalması insanda kalp krizi riskinden $\mathrm{KOAH}$, astım gibi solunum hastalıklarına neden olarak yaşam kalitesini bozar (Kardeşoğlu vd., 2011, s.102). Türk Tabipleri Birliği'nin de aralarında bulunduğu beş hekim ve tıbbi uzmanlık kuruluşunun basın açıklamasında yer alan verilere göre Türkiye' de, hava kirliliğinden kaynaklı ölüm oranları çok yüksektir. ${ }^{33}$ Görüldüğü üzere sermayenin doğa üzerinde kurduğu tahakküm, insanların yaşam kalitesini artırdığını belirten söylemler üzerinde inşa ederken toplumun çoğunluğu bu durumdan negatif etkilenir.

2015 yılında Paris'te gerçekleştirilen COP21 konferansında küresel ısınmanın düşük seviyede tutulması konusunda varılan uzlaşı umut aşılasa da popülist liderlerin tutumları ve günümüz karbon salımı verileri bilim adamlarının uyarılarının dikkate alınmadığını göstermektedir. Hatta Donald Trump'ın başkan olduktan sonra yaptığı

\footnotetext{
${ }^{31}$ Kömürlü termik santrallerle ilgili siyasal iktidarın söylemleri şu şekildedir: "Biz bu ülkede karanlık bir köy görmek istemiyoruz. Tüm tesislerimizin makinelerini takır takır çalıştı̆̆ bir Türkiye'yi yaşamak istiyoruz. Bütün kömür rezervlerimizi kullanmak durumundayız ve bunu da başaracağız... Dün darbecilere, vesayetçilere gönüllü yardım edenler, bugün de Türkiye'nin enerji yatırımlarını baltalamak isteyenlere piyonluk yapıyor. Kimse aksini iddia etmesin, herkes kullanırken bu ülkede kömüre karş1 çıkmak demek ‘Türkiye kendi kaynaklarını değerlendirmesin' demek değil midir, nükleer güç santrallerine karşı çıkmak 'Türkiye enerjide dışa bağımlı olsun' demek değil midir, barajlara karşı çıkmak her yıl milyarlarca dolarımızın dışarıya akıtılmasına aracılık etmek demek değil midir?" http://www.iha.com.tr/ankara-haberleri/turkiye-1-yilda-devreye-giren-uretim-santralleri-bakimindanyeni-bir-rekora-imza-atti-1858769. Ancak buradaki temel sorun özelleştirilen santrallerin çevre mevzuatına uyumuna yönelik yatırımların sürekli kanun maddeleri ile güncellenmesi ve sürenin belirli aralıklarla uzatılmasıdır. https://www.epdk.org.tr/Detay/Icerik/3-0-0-2256/kanunlar

32 http://www.tuik.gov.tr/HbPrint.do?id=8512; https://webdosya.csb.gov.tr/db/ced/icerikler/bulten-subat2019-20190412173214.pdf

${ }^{33}$ http://www.ttb.org.tr/haberarsiv_goster.php?Guid=1083e0b0-d44f-11e7-acb3-e8c5204e2ae7
} 
açıklamalarda ABD'nin diğer ülkelere karşı ekonomik bağlamda dezavantajlı konuma düşeceği gerekçesiyle anlaşmadan vazgeçmesi, Brezilya ve Türkiye gibi popülizmin yükseldiği ülkelerin de anlaşmayı benimsemediklerini açılamalar ${ }^{34}$ ve bunu kendi ülke menfaatleri için yaptıklarını ifade etmeleri anlaşmanın kırılgan yapısına işaret eder. Böylece ulus aşırı şirketler ve devletlerarası politikaların çıkarları doğrultusunda doğanın geri döndürülmez bir tahribata uğrayacağı düşüncesi yok sayılır. Zira yukarıda da bahsedildiği üzere ulus aşırı petrol şirketleri fosil yakıtlardan kaynaklanan küresel ısınmayı yok saymak için dezenformasyon üretir. Keza bu dezenformasyon siyasal iktidar tarafından enerji sıkıntısının çözümü ve ekonomik gelişme gibi söylemlerle meşrulaştırılır (Kadığlu, 2001, s. 6). Bu bağlamda şu soru hemen akla gelmektedir: Gezegenin tümünü kapsayan bir sorunun en azından farkına varıp gerekli engellemeleri yapanların tarafında olmak mı yoksa kendi çıkarları doğrultusunda kısa bir süre kâr oranlarını yüksek seviyede tutarak ekonomik, toplumsal ve siyasal dengeyi popülist söylemlerle bir arada tutanların tarafında olmak mı? Konu ile ilgili Bruno Latour (2017, s.103), günümüzde temel ayrışmanın bu konu üzerinde şekillendiğini belirtir:

Küreselleşmenin “Küre'sinin barınacağ bir gezegen, yer, toprak, bölge yoksa tüm ülkeler bunlardan hangisine yöneliyormuş gibi yapacak, ne yapacağız? Ya sorunun varlığını inkar edeceğiz ya da ayaklarımızı yere basmaya çalışacağız. Her birimiz için soru şuna dönüşüyor: Kaçış hayallerini beslemeye devam mı edeceksiniz, yoksa siz ve çocuklarınız için yaşanabilir bir alan aramaya başlayacak mısınız? İnsanları ayrıştıran soru sağcı, solcu olmaktan öte bundan böyle bu."

Latour'un ifade ettiği gibi küreselleşme olgusu ile birlikte tüm kurumsal politikalarda meydana gelen değişimlerle birlikte dünya üzerinde yaşanan -yaşanacak- problemlerin niteliğinde/niceliğinde de değişimler yaşanmaya başlamıştır. Bu bağlamda günümüz popülist liderlerinin aldıkları kararların salt kendi ulusal çıarlarından ziyade tüm küreyi kapsadığı anlaşılır bir zemine oturur. Zira doğanın sürekli tahrip edilerek canlı türlerinin habitatlarının zarar görmesi ve iklim değişikliği gibi olumsuz gelişmeler tüm dünyayı ilgilendiren kitlesel yok oluşlara neden olacaktır. Francisco Sánchez-Bayo ve Kris A.G. Wyckhuys'un (2019, s.8) yaptığı bilimsel araştırma verileri, yaklaşık on yıl içinde böcek türlerinin yüzde kırkının neslinin tükenebileceğini ortaya koyar. Bu

\footnotetext{
${ }^{34}$ Konu ile ilgili Dışişleri Bakanlığı'nın resmi sitesinden yapılan açılama, “Anlaşma'nın farklılaştırmaya imkân vermeyecek şekilde oluşturulması; Sözleşme'nin Ek sistemine atıfta bulunmaması, ülkemizin “özel koşulları"nın Paris Anlaşması'na veya COP 21 kararlarına dercedilmesine imkân vermemiştir" şekildedir. http://www.mfa.gov.tr/bm-iklim-degisikligi-cerceve-sozlesmesi.tr.mfa
} 
bakımdan endüstriyalizmin bir sonucu olarak gerçekleşen doğa tahribatının iklim değişikliği, göç, hava kirliliği, ormansızlaşma gibi birçok olumsuz sonuçlar doğurarak canlı türlerinin yok olmasına bağlı ekolojik yıkımlara neden olacağı düşünülmelidir.

Hakikat sonrası demokraside medyanın bilgilendirme işlevini yitirdiği düşüncesinden hareketle ${ }^{35}$-ve sosyal medya üzerinden doğru bilgiye ulaşmanın giderek olanaksızlaşması nedeniyle- toplum akılcı tercihleri terk ederek çoğunlukçu politikalara teslim olur. Yerel ya da küresel problemleri akılcı bir yöntemle çözmek yerine duygularını takip ederek popülist söylemlere inanma eğilimi gösteren 'hakikat sonrası birey', Tolstoy'un romanındaki Stepan Arkadyeviç'e benzer bir şekilde davranmaya başlar. Bu durum bireyi gelecekte yaşanabilecek ya da şu an yaşanan problemleri tümel bir gözle anlamlandırma çabasından mahrum eder. Böylece siyasal iktidar ve küresel sermayenin ilişkisini doğa tahribatı üzerinden kendisine hizmet olarak sunulduğunu zanneden birey, gerçekliğin bozulması ve hakikatin kaybolması nedeniyle popülist söylemleri kendi çıkarını gözettiği için destekler.

\section{Sonuç}

Hakikat sonrası dönem olarak nitelendirilen günümüzde siyaset yapma biçimi geçmişe nazaran daha sert bir hal almaya başladı. Özellikle son dönemde demokrasinin beşiği olarak adlandırılan Batı'da yükselen popülist söylemler günümüzde demokrasinin anlamını değiştirmeye ve daha otoriter bir yapı içinde kendisini yeniden tanımlamaya zorlar. Küreselleşme söylemleri ile birlikte demokrasinin içine girdiği kriz, vekil ve halk arasındaki temsil mekanizmasının geçerliliğinin sorgulanmasına neden olduğundan sürekli referandumlarla halka söz hakkı veren popülist güçlü bir liderin varlığı temsil edilmeyen çoğunluğun öfkesini göstermesi için imkan tanır. Bu imkanı ise kamu yararı güden politikalardan uzaklaşıp siyasal iktidar ve sermaye yararına kar amacı günden politikaları benimseyen, bireylerin nesnel hakikatlerden giderek uzaklaşmasına dini ve milli duygular başta olmak üzere nesnel olmayan hakikatlere yakınlaşmasına neden olan medya araçları verir. Siyasal iktidar, sermaye ve medya arasında kurulan ilişkiler yumağı halkın duygularını "gerçek olmayan gerçekler" üzerinden yönlendirebildiğinden doğa üzerine kurulan tahakküm de belirli bir meşruiyet düzeninde medya araçları ile halka kolaylıkla sunulur. Bütün bu sorunlar, doğanın halka hizmet, dış güçlere karşı en büyük görünme arzusu veya güvenlik politikaları nedeniyle nesneleştirilip verimsizleştirilmesi uzun vadeli problemlerin göz ardı edilmesini sağlar.

\footnotetext{
${ }^{35} 2002$ yılından bugüne medyada gerçekleşen yapısal dönüşümü incelemek için Bkz. Aydın, U. (2015).
} 
Bugün içinde bulunduğumuz koşullar itibariyle doğanın iklim değişikliği, hava kirliliği gibi canlı yaşamını tehlikeye sokacak sonuçlar doğurduğu bir dönemdeyiz. Küresel kapitalist sermayenin sürekli büyüme istemi çerçevesinde içinde bulunduğu krizleri aşmak için yeni yatırım alanlarını büyük tepkisellikler yaratmadan gerçekleştirebilmesi için gerekli olan siyasal zemin de popülist iktidarlar tarafından sağlansa da kısa vadeli çözümlerin gelecekte daha büyük problemler yaratacağ1 unutulmamalıdır. Bu nedenle modernliğin en tehlikeli sonuçlarından biri olan endüstriyalizmin doğaya verdiği zarar minimal seviyede tutulursa ancak geleceğe yaşanabilir bir dünya miras bırakılabilir.

\section{Kaynaklar}

Adorno, T.W. (1998). Minima Moralia. (Orhan Koçak ve Ahmet Doğukan Çev.), İstanbul: Metis.

Adorno, T.W., Horkheimer, M. (2014). Aydınlanmanın Diyalektiği (Nihat Ülner, Elif Öztarhan Karadoğan Çev.). İstanbul: Kabalcı

Appadurai, A. (2017). Demokrasi Yorgunluğu (s. 17-29). Büyük Gerileme: Zamanımızın Ruh Hali Üstüne Uluslararası Bir Tartışma (Heinrich Geiselberger Edt.). İstanbul: Metis.

Artık Eski Türkiye Olmayacak, Şimdi Yeni Türkiye'yi İnşa Edeceğiz. Erişim: 18 Nisan 2019, https://www.tccb.gov.tr/haberler/410/32254/artik-eski-turkiye-olmayacaksimdi-yeni-turkiyeyi-insa-edecegiz

Aydın, U. (2015). Neoliberal Muhafazakar Medya, İstanbul: Ayrıntı.

Başbakan'ın notları iPad'de. Erişim: 21 Nisan 2019, http://www.hurriyet.com.tr/gundem/basbakanin-notlari-ipadde-17737311

Baykan T. S. (2017). Halkçılık ve Popülizm: Türkiye Vakası ve Bir Kavramın Kullanımları. Mülkiye Dergisi, 41 (1), 157-194.

Bayrakdar, M., Durmaz, V. (2014). Environmental Impacts of Airports: A Research on The Istanbul 3rd Airport, ISEM Sempozyumu, 769-779.

Belge, M. (2018). Siz İsterseniz... Popülizm Üzerine Yazılar. İstanbul: İletişim.

Bezmez, T.Y. (2018) Neo-liberal Düzlemde Popülist Söylem. Uluslararası Politika Akademisi, Erişim http://politikaakademisi.org/2018/08/16/neo-liberal-duzlemdepopulist-soylem/

Bilge, M. (2011). Türkiye'de Demokrasi Kültürü: Siyaset ve Toplum. TSA, 15(3).

BM İklim Değişikliği Çerçeve Sözleşmesi, Erişim: 24 Şubat 2019, http://www.mfa.gov.tr/bm-iklim-degisikligi-cerceve-sozlesmesi.tr.mfa 
Bozkurt, U. (2013). Neoliberalism with a Human Face: Making Sense of the Justice and Development Party's Neoliberal Populism in Turkey. Science \& Society, 77(3), 372396. https://doi.org/10.1521/siso.2013.77.3.372

Brown, M.B. (2014). Climate Science, Populism, and the Democracy od Rejection. Culture, Politics and Climate Change (Deserai A. Crow, Maxwell T. Boykott Edt.). New York: Routledge.

Bu Topraklar Üzerinde Gözü Olanlar, Bedelini Çok Ağır Ödüyor. Erişim: 16 Nisan 2019, https://www.tccb.gov.tr/haberler/410/43999/bu-topraklar-uzerinde-gozu-olanlarbedelini-cok-agir-oduyor

Climate change: How do we know? Erişim: 24 Şubat 2019, https://climate.nasa.gov/evidence

Corner, J. (2017). Fake news, post-truth and media-political change. Media, Culture $\mathcal{E}$ Society, 39(7), 1100-1107. https://doi.org/10.1177/0163443717726743

Cumhurbaşkanı Erdoğan: Tek parti zihniyeti ve darbeci kafa aynı madalyonun iki yüzü gibidir. Erişim: 18 Nisan 2019, https://www.aa.com.tr/tr/turkiye/cumhurbaskanierdogan-tek-parti-zihniyeti-ve-darbeci-kafa-ayni-madalyonun-iki-yuzugibidir/1307552

Daragahi, B. (25 Haziran 2018) Erdogan Has Mastered Democracy. Foreign Policy. Erişim: 13 Nisan 2019, https://foreignpolicy.com/2018/06/25/erdogan-has-mastereddemocracy

Delanty G. (2019) Europe in the Short Twentieth Century: Conflicting Projects of Modernity. Formations of European Modernity, Cham: Palgrave Macmillan, 265-301.

Demirkent, D. (2013). Demokratikleşme Paketi, Ayrıntı Dergi, Sayı 1, İstanbul:Ayrıntı.

Dyer, G. (2013). İklim Savaşları: Dünya Aşırı Isınırken Hayatta Kalma Mücadelesi (Füsun Özlen Çev.). İstanbul: Paloma.

Eight reasons Leave won the UK's referendum on the EU. Erişim: 8 Mart 2019, https://www.bbc.com/news/uk-politics-eu-referendum-36574526

Elektrik Piyasası Kanunlar Listesi. Erişim: 13 Mart 2019, https://www.epdk.org.tr/Detay/Icerik/3-0-0-2256/kanunlar

Erdem, F.H. ve Coşkun, V. (2009). Askeri Yargı ve Askeri Vesayet, SETA Analiz, Sayı 9, Erişim http://file.setav.org/Files/Pdf/askeri-yargi-ve-askeri-vesayet.pdf.

Erdoğan: 'Hayır' diyen darbecidir. Erişim: 19 Nisan 2019, https://www.ntv.com.tr/turkiye/erdogan-hayir-diyendarbecidir,bQHGDGasykazMmycFR3roA 
Erdoğan: Oy Hangi Yönde Olursa Olsun Saygındır, Muteberdir. Erişim: 21 Nisan 2019, https://t24.com.tr/haber/erdogan-oy-hangi-yondeolursa-olsun-saygindirmuteberdir-ankara-aa, 97547

Fraser, N. (2017a). The End of Progressive Neoliberalism. Dissent. http://www.bresserpereira.org.br/terceiros/2017/fevereiro/17.02-End-ofProgressive-Neoliberalism.pdf

Fraser, N. (2017b). İlerici Neoliberalizme Karşı Gerici Popülizm: Bir Hobson Seçimi (Merisa Şahin vd. Çev.). (s. 59-68) Büyük Gerileme: Zamanımızın Ruh Hali Üstüne Uluslararası Bir Tartışma. (Heinrich Geiselberger Edt.). İstanbul: Metis.

Freud, S. (2014). Mutlu Olma İhtimalimiz (Mustafa Fırat Çev.). İstanbul: Zeplin.

Galeano, E. (2017). Tepetaklak (Bülent Kale Çev.). İstanbul: Sel.

Giddens, A. (2012). Modernliğ̈in Sonuçları (Ersin Kuşdil Çev.). İstanbul: Ayrıntı.

Hardt, M., Negri, A. (2003). İmparatroluk (Abdullah Yılmaz Çev.). İstanbul: Ayrıntı.

Hava Kalitesi Bülteni Şubat 2019, Erişim: 18 Nisan 2019, https://webdosya.csb.gov.tr/db/ced/icerikler/bulten-subat-201920190412173214.pdf

Hava Kalitesi İstatistikleri, 2010-2011 Kış Sezonu. Erişim: 18 Nisan 2019, http://www.tuik.gov.tr/HbPrint.do?id=8512

Hekim örgütleri hava kirliliği konusunda alarmda. Erişim: 13 Mart 2019, http://www.ttb.org.tr/haberarsiv_goster.php?Guid=1083e0b0-d44f-11e7-acb3e8c5204e2ae7

Heper, M. (2000). The Ottoman Legacy and Turkish Politics. Journal of International Affairs, 54(1), 63-82.

Hintz, L. (2015). Fighting for Us, Inside and Out: National Identity Contestation and Foreign Policy in Turkey. (Yayımlanmamıs Doktora Tezi). The Faculty of The Columbian College of Arts and Sciences of The George Washington University, Washington.

Hook, L. (2 Aralık 2018) Climate change: populism vs Paris. Financial Times, Erişim: 08 Şubat 2019, https://www.ft.com/content/acd0e8b6-f3d2-11e8-ae55-df4bf40f9d0d İstanbul 27 Temmuz 2017 afeti! 9 gün sonra ikinci kâbusu yaşadık. Erişim: 10 Mart 2019, https://www.sozcu.com.tr/2017/gundem/istanbul-27-temmuz-2017-afeti-9-gunsonra-ikinci-kabusu-yasadik-1949885

İstanbul'da sel felaketi: 31 ölü. Erişim: 10 Mart 2019, http://www.hurriyet.com.tr/gundem/istanbulda-sel-felaketi-31-olu-12441217

İstanbul'u sel aldı. Erişim: 10 Mart 2019, http://www.hurriyet.com.tr/gundem/istanbulusel-aldi-23503755 
Kadığlu, M. (2001). Bildiğiniz havaların sonu: küresel iklim değişimi ve Türkiye, İstanbul: Güncel.

Kant, I. (1984). Seçilmiş Yazılar (Nejat Bozkurt Çev.). İstanbul: Remzi.

Kantaş, Ö. (2015). Kronik: “Madenin altı ölüm; üstü zulüm...”, Ankara Üniversitesi Siyasal Bilgiler Fakültesi Dergisi, 70(2), 485-497.

Kardeşoğlu, E., Yalçın, M., Işılak, Z. (2011). Hava Kirliliği ve Kardiyovasküler Sistem, TAF Preventive Medicine Bulletin, 10(1), 97-106.

Karpat, K.H. (1996). Türk Demokrasi Tarihi- Sosyal, Ekonomik, Kültürel Temeller, İstanbul: AFA Yayınları.

Keser, N. (2002). Kütahya'da Hava Kirliliğine Etki Eden Topografik ve Klimatik Faktörler, Marmara Coğrafya Dergisi, Sayı 5, 69-100.

Keyman, E. F. (2008). Türkiye'nin İyi ve Adaletli Yönetimi ve Sosyal Demokrasi. Toplum ve Demokrasi, 2 (2), 1-13.

Kırış, R., Toprak, S. (2009). İklim Değişikliğinde Ormanların Rolü, TÜCAUM V. Ulusal Coğrafya Sempozyumu, 379-385.

Kingsley, P. (20 Temmuz 2016) 'We see him as one of us': why many Turks still back authoritarian Erdoğan. The Guardian. Erişim: 16 Nisan 2019, https://www.theguardian.com/world/2016/jul/20/we-see-him-as-one-of-us-whymany-turks-still-back-authoritarian-erdogan

Kitcher, Philip (2011). Science in a democratic society. MA: Prometheus Books

Kongar, E. (2001). Demokrasi Kültürü Sorunları, Kültürel Açıdan Avrupa Birliği'ne Yaklaşım Sempozyumu, $\quad$ İstanbul. Erişim https://www.kongar.org/makaleler/Demokrasi_Sorunlari.php.

Köker, L. (2007). Modernleşme, Kemalizm ve Demokrasi, İstanbul: İletişim.

Latour, B. (2017) Güvenli Avrupa (Merisa Şahin vd. Çev.). (s. 101-110) Büyük Gerileme: Zamanımızın Ruh Hali Üstüne Uluslararası Bir Tartışma. (Heinrich Geiselberger Edt.). İstanbul: Metis.

Lewis, B. (1994). Why Turkey Is The Only Muslim Democracy. Middle East Quarterly, 1(1), 41-49. https://dev.meforum.org/216/why-turkey-is-the-only-muslimdemocracy

Lewis, P., Barr, C., Clarke, S., Voce, A., Levett, C., Gutiérrez, P. (6 Mart 2019). Revealed: the rise and rise of populist rhetoric. The Guardian. Erişim: 13 Mart 2019, https://www.theguardian.com/world/ng-interactive/2019/mar/06/revealed-therise-and-rise-of-populist-rhetoric 
Lockwood, M. (2017). Right wing populism and climate change: Exploring the linkages. Political Studies Association Annual Conference, Erişim https://www.psa.ac.uk/sites/default/files/conference/papers/2017/Right\%20wing\% 20populism\%20and\%20climate\%20change.pdf

Mardin, Ş. (1991). Türk Modernleşmesi: Makaleler 4, İstanbul: İletişim.

Milletimiz Bizimle Birlikte Yeni Türkiye'yi, Yeni Anayasayı ve Başkanlık Sistemini İstiyor. $\quad$ Erişim: 18 Nisan 2019, https://www.tccb.gov.tr/haberler/410/32353/milletimiz-bizimle-birlikte-yeniturkiyeyi-yeni-anayasayi-ve-baskanlik-sistemini-istiyor

Millî İradeye Herkesin Sayg1 Duyması Lazım. Erişim: 18 Nisan 2019, https://www.tccb.gov.tr/haberler/410/74834/mill-iradeye-herkesin-saygi-duymasilazim.html

Mishra, P. (2017). Hınç Çağında Siyaset: Aydınlanma'nın Karanlık Mirası (s.128-142). Büyük Gerileme: Zamanımızın Ruh Hali Üstüne Uluslararası Bir Tartışma (Heinrich Geiselberger Edt.). İstanbul: Metis.

Moffitt, B. (2016). The Global Rise of Populism Performance, Political Style, and Representation, California: Standford University Press.

Müller, J.W. (2017). Popülizm Nedir?. (Onur Yıldız Çev.) İstanbul: İletişim

O'Donnell, A. (2018). Neoliberalism, ambiguity and the rise of populist movements. International Journal of Social Economics, 45(7) ,1030-1041. doi:10.1108/IJSE-05-20170202

Oskay, Ü. (2014). Tek Kişilik Haçlı Seferleri, İstanbul: İnkılap.

Oynanan Oyunlara Karşı Milletimizle Omuz Omuza, Tarihî Bir Mücadele Verdik. Erişim: 16 Nisan 2019, https://www.tccb.gov.tr/haberler/410/77664/oynanan-oyunlarakarsi-milletimizle-omuz-omuza-tarih-bir-mucadele-verdik

Öztürk, A. (2015). İzlenimler AKP Türkiye'si, İstanbul: Gündoğan.

Platter, M. C. (2010). Populism, Pluralism, and Liberal Democracy. Journal of Democracy, 21(1).

Plattner, M. F. (2010). Democracy's Past and Future: Populism, Pluralism, and Liberal Democracy. Journal of Democracy 21(1), 81-92.

Polanyi, K. (2017). Büyük Dönüşüm: Çağımızın Siyasal ve Ekonomik Kökenleri (Ayşe Buğra Çev.). İstanbul: İletişim.

Pühringer, S., Ötsch, W.O. (2018) Neoliberalism and Right-wing Populism: Conceptual Analogies. Forum for Social Economics, 47(2), 193-203, doi:10.1080/07360932.2018.1451765 
Saç, S. (2017). Front National: Radikal (Popülist) Sağdan (Ilımlı) Neo-Popülist Sağa. Mülkiye Dergisi, 41(1), 259-290.

Sánchez-Bayo, F., Wyckhuys, K.A.G. (2019). Worldwide decline of the entomofauna: A review of its drivers, Biological Conservation, 232, 8-27.

Schmitt, C. (2006). Parlamenter Demokrasinin Krizi, (Emre Zeybekoğlu Çev.). Ankara: Dost.

Skinner, G. (2018). Beyond Populism? Two Years After, Erişim: 12 Mart 2019, https://www.ipsos.com/en/beyond-populism-two-years-after

Taguieff, P. (1997), Le populisme et la science politique. Du mirage conceptuel aux vrais problèmes, Vingtième Siècle. Revue D'histoire, (56), 4-33. doi:10.2307/3770596.

Telek, A. (2017). Popülizme Karşı (III): Küresel Adalet İhtiyacı Işığında Hindistan ve Macaristan. Birikim Dergisi, Erişim http://www.birikimdergisi.com/guncelyazilar/8550/populizme-karsi-iii-kuresel-adalet-ihtiyaci-isiginda-hindistan-vemacaristan.

The Inaugural Address. Erişim: 17 Nisan 2019, https://www.whitehouse.gov/briefingsstatements/the-inaugural-address

TMMOB İstanbul İl Koordinasyon Kurulu 3. Havalimanı Teknik Raporu, Aralık 2014, https://www.tmmob.org.tr/sites/default/files/3.havalimani_ikk_rapor_20141208.pd $\mathrm{f}$

Toprak, Z. (1992). Popülizm ve Türkiye'deki Boyutları, (s. 41-65) Tarih ve Demokrasi - Tarı Zafer Tunaya'ya Armağan, İstanbul; Cem Yayınları.

Tunçer, S. (2018). Reinterpreting Crisis Communications in the Post-Truth Era. Moment Journal, 5(2), 368-382.

Türk Milleti Olarak Dünyaya Son Sözümüzü Henüz Söylemedik. Erişim: 16 Nisan 2019, https://www.tccb.gov.tr/haberler/410/87738/turk-milleti-olarak-dunyaya-sonsozumuzu-henuz-soylemedik.html

Türkiye, 1 yılda devreye giren üretim santralleri bakımından yeni bir rekora imza attı. Erişim: 13 Mart 2019, http://www.iha.com.tr/ankara-haberleri/turkiye-1-yildadevreye-giren-uretim-santralleri-bakimindan-yeni-bir-rekora-imza-atti-1858769

twitter.com/rt_erdogan/status/264675211675332609

twitter.com/rt_erdogan/status/309308978544930816 twitter.com/rt_erdogan/status/475296968009609216 Visvizi, A. (2017). Querying the Migration-Populism Nexus: Poland and Greece in Focus, IED Discussion Paper, July 2017, Brussels: Institute of European Democrats. 
Yanatma, S. (2018). Reuters Institute Digital News Report 2018: Turkey Supplementary Report. Reuters Institute for the Study of Journalism, Erişim: 8 Mart 2019, https://reutersinstitute.politics.ox.ac.uk/sites/default/files/2018- 